\title{
1. Leadership, social development and political economy in the Middle East: an introduction
}

\author{
Beverly Dawn Metcalfe and Tony Murfin
}

Hold fast to God's rope all together; do not split into factions. Remember God's favour to you: you were enemies and then He brought your hearts together and you became brothers by His grace; you were about to fall into a pit of Fire and He saved you from it - in this way God makes his revelations clear to you that you may be rightly guided.

Qur'an, sura, The Family of 'Imran, 3:128

Among the Arabs there were no distinctions, traditional or natural, except the unconscious power given a famous sheikh by virtue of his accomplishment; and they taught me that no man could be their leader except he ate the ranks' food, wore their clothes, lived level with them, and yet appeared better in himself.

T.E. Lawrence, The Seven Pillars of Wisdom, 1926

This volume advances scholarship of leadership theorizing by exploring the socio-cultural, political and economic context of leadership identity formation in the Middle East. Central to this analysis is the role of Islam in shaping leadership behaviour and social practices. Our contention is that Islamic philosophy and science are at the very heart of conceptualizing leadership roles and relations in the Middle East, but are often silenced in contemporary global discourse.

We begin this chapter by investigating the historicization of Islamic cultural and intellectual heritage and the legacy of the period immediately following the death of the Prophet Muhammad in which Islamic leadership traditions were formed (Campbell 2008). Current theological scholarship attempts to reinterpret and reimagine the dynamic processes of leadership and we position these arguments within contemporary discourses of leadership in the Islamic world. As the contributors maintain throughout the book, the retrieval and renewal of such insights are vital if scholars, whether in theology, development, management, economics, women's studies or sociology, are to achieve new insights into the 21 st century world of leadership, and for new, marginalized voices to emerge from that world.

We go on to discuss how re-Islamization, or Islamic resurgence, has 
recently grown all over the world. We show how this relates to processes of Westernization and globalization, their cultural interaction and the complex activity of mapping leadership practices. In exposing how Western and Islamic civilizations are historically entwined, we also identify opportunities for mutual exchange, growth and development.

We then summarize the historical development of Western leadership theory and practice, showing how a focus on leadership traits and competences has moved on to consider situational factors, the leader's relationship with followers and critical accounts including social constructionist approaches. Finally, we briefly review contemporary thinking on leadership and ethics as it relates to our considerations of Middle East leadership ideology and practice. Building on this debate, we review leadership thinking through an Islamic lens. Here, we emphasize the significance of moral codes and ethical conduct and stress a radical departure from Western models, with their focus on leadership in organizations, to one that engenders the holistic development of an individual's intellectual and spiritual identity, as well as the social transformation of communities and societies.

To position our debate, we feel it appropriate and necessary to define the geographic territories of the Middle East and their role and historical significance in the global political economy. We will outline the religious, dynastic and colonial forces that have shaped national boundaries in the region, putting into perspective the areas in which specific Islamic traditions are prevalent and making postcolonial legacies evident. We will examine human development in a region which contains states in widely differing stages of economic, social and political development. We position the Middle East centre-stage in the global political economy by stressing the significance and power of the region in terms of natural resources in the form of oil and gas, while acknowledging that these resources have a complex relationship in the fabric of the international political economy, impacted by the complexity of power relations between international development agencies, nation states and regional networks such as OPEC (Bebbington 2008; Utting 2006). Unequal power dynamics and relations in shaping economic and social agendas are further highlighted in a region which can be considered as divided between resource-rich and resourcepoor economies. Finally, we discuss the vulnerabilities and opportunities in the region in its response to current and future development and environment issues including 'peak oil', water resources, population growth, global trade routes and global warming, including opportunities in alternative energy resources.

We do not intend this text to merely restate myriad leadership theories, but rather to go some way in opening up communication and dialogue 
and thereby to reinterpret and reintegrate the knowledge territories of East and West (Escobar 1998; Ramadan 2009), and help re-imagine development discourses (Crush 1998). In doing so, we hope to unveil and open out the possibility of envisioning alternative development leadership paradigms inspired by knowledge from the Global South, as well as those, largely untranslated, Arabic texts that have shaped and influenced Middle Eastern thinking, reflection and comprehension: texts that build on a tradition of thought and intellectual investigation that was once the common link between both East and West civilizations and the scholarship of antiquity (see, inter alia, Morgan 2007; Ramadan 2009), a connection that the West and the Global North are belatedly rediscovering (Asutay and Zaman 2009; Morgan 2007).

The dynamic of political leadership and its intimate connection with leadership strategies in organizations is unfolded in this introduction (Platteau 2010). Weaving together the knowledge territories of development studies, organization and management, human resource development and environmental agendas with Islamic scholarship, we provide a rich account of the complexities of leader behaviours in the Middle East and the challenges that development stakeholders face to build leadership knowledges and human capabilities as the twenty-first century progresses.

\section{CULTURE, POLITICAL ECONOMY, RELIGIOPOLITICS AND INTERNATIONAL RELATIONS}

\section{The Legacy of History}

Our perception of the past depends on how we choose to collect and assemble the mosaic pieces of history - in the words of Arthur Miller (1947), 'the past is always present, and cannot be ignored, forgotten or denied' - yet it is absolutely essential to assemble those pieces correctly if we are to construct an understanding of the Middle East in which prosperity, stability and inter-state collaboration can be achieved (Ramadan 2004, 2009; Woolgar 1978). As Lewis and Churchill (2009) argue, the rehistoricization of social and political processes reveals insights that may otherwise fade away and be lost.

Islam has been pained for centuries by events that took place in the 50 -year period following the death of the Prophet Muhammad in $632 \mathrm{CE}$. The Sunni majority of Muslims believe that Muhammad died having left no instruction as to who, if anyone, should succeed him in the Islamic 
community; but some believed that he had designated his son-in-law Ali as his successor. This group, the partisans of Ali (Shiat Ali), were later to be called Shi'a (Campbell 2008; Cleveland and Bunton 2009; Esposito 2005; Wilson 1985; see also discussion in the Editors' preface). These events gave rise to enduring ruling dynasties but also produced a schism between the Sunni and Shi'a. From this historic turmoil, distinctive leadership styles would develop and schools of thought on leadership would grow up which can only be understood in the context of the region, its history and culture, and the processes that formed the historical and modern states. Although there is an enduring legacy of colonial involvement in the region, to assume that this is the only, or even the dominant cultural influence is inaccurate and hubristic (Halliday 2010), and Western models are incomplete or inadequate to understand the reality of leadership in this complex region. While we acknowledge that cultural ideologies are shaped by a society's location in the hierarchically organized global economy, it is important to appreciate that they also vary according to the organization and development discourses that have evolved (Escobar 1998), and the historical and social context in which they have been embedded in each country (Crush 1998; Fairclough and Chiapello 2005; Woolcock 1998).

Leadership succession, long a central concern of the region, became an issue of global urgency beginning in December 2010 and continuing into 2011. The issue of political leadership succession to long-serving and relatively aged rulers in Egypt, Oman and Saudi Arabia was well known, but no one could have predicted the decisive mass action that caused, first, Zine El Abidine Ben Ali to be forced out of power in Tunisia and then Hosni Mubarak to be deposed in Egypt. Other protests have occurred in Bahrain - where they have been violently suppressed - Algeria, Jordan, Iran, Syria and Yemen. Libya has descended into civil war. Table 1.1 gives a summary of current governance regimes and the current leaders of selected states in the region. This is correct at July 2011.

As can be seen in Table 1.1, of the 11 nations considered, five have heads of state born in or before the year 1940. It should be noted that there is no single method to determine succession common to these states and no simple rule of succession such as primogeniture. In all cases, however, there is a degree of consensus (ijma) involved in appointing a legitimate successor.

The questions that remain of who will take control, and who should be involved in choosing a successor, are central to contemporary international relations and development, just as they were to the Muslim world in the early decades of Islam, and some commentators have suggested that the Muslim world faces the same problems it has faced since 


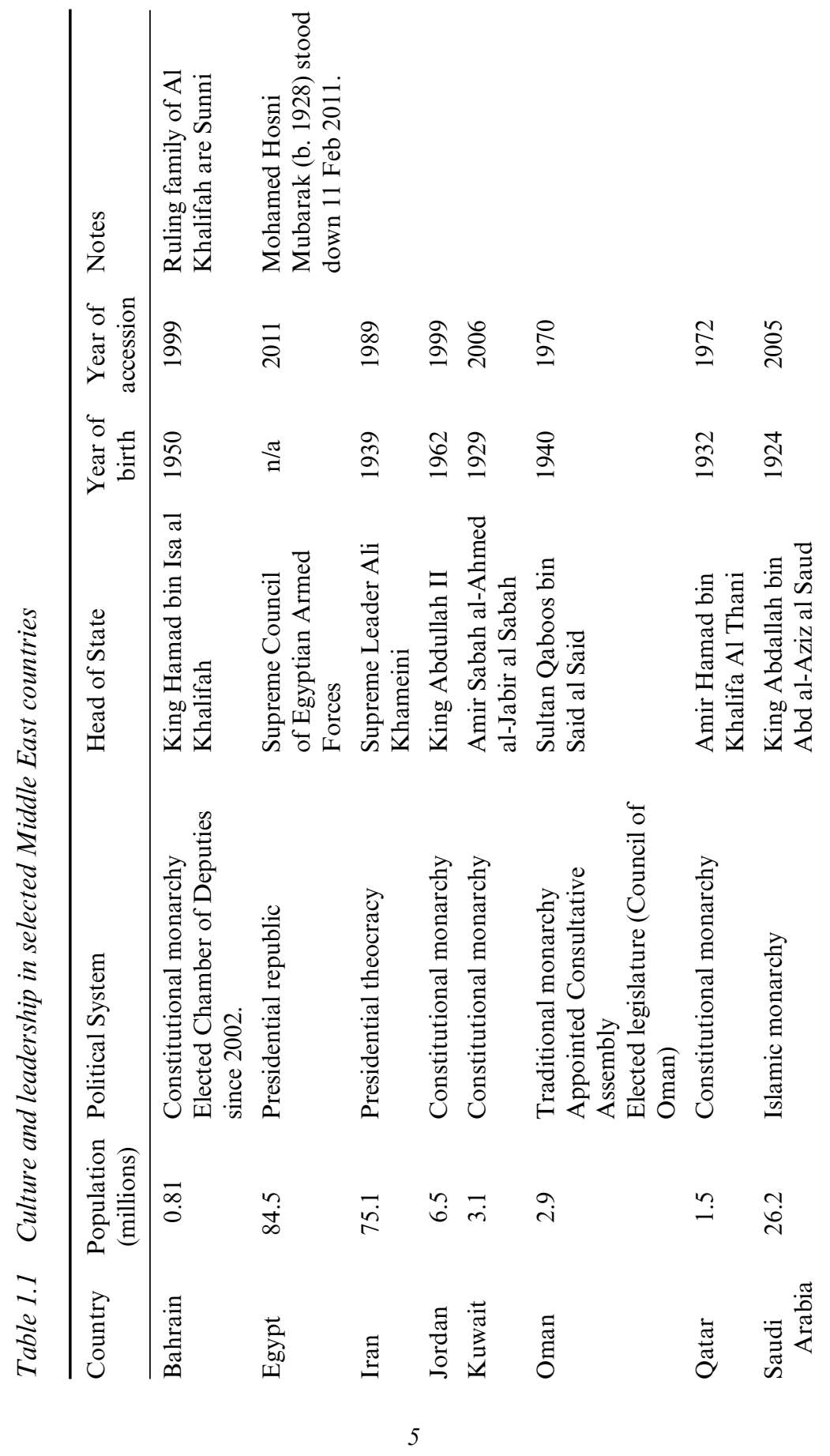




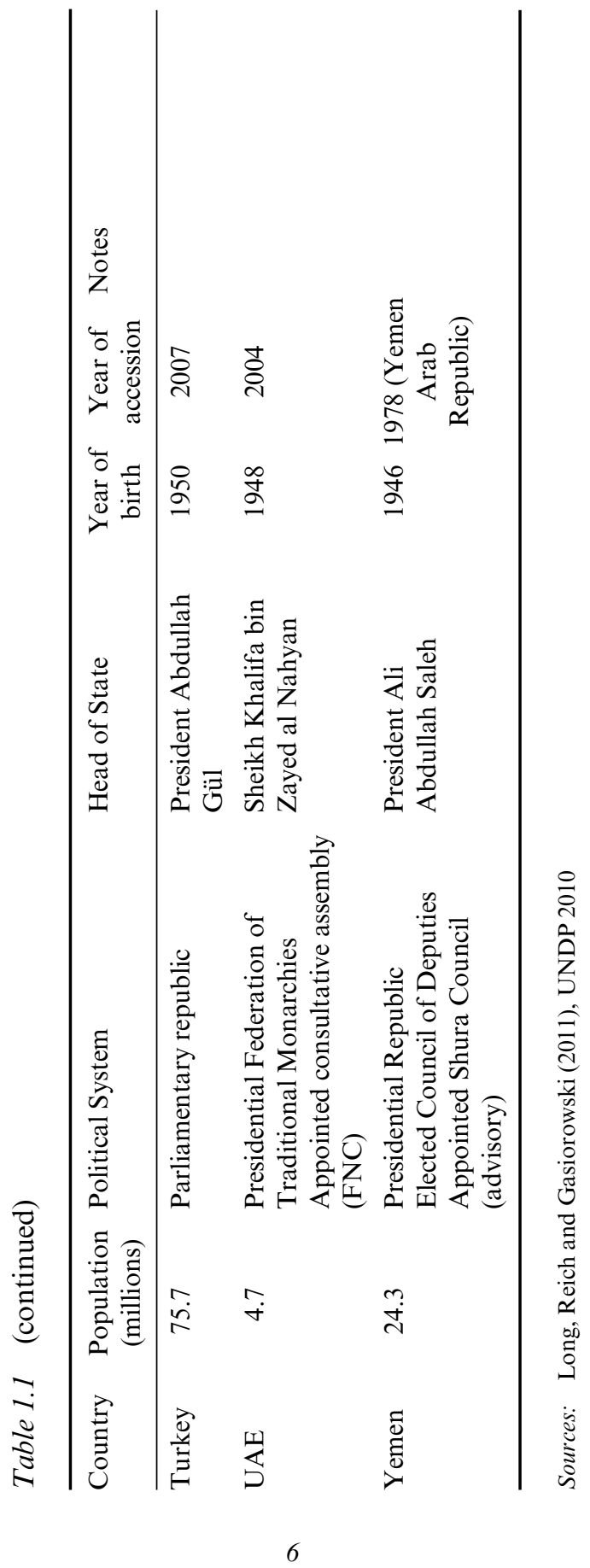


its inception: that same issue of succession to the Prophet Muhammad (Cleveland and Bunton 2009; Rodenbeck 2010; Platteau 2008). As Berkey (2003) argues:

. . probably no set of issues proved so contentious to Muslim posterity, or so critical in subsequent definitions of what it meant to be a Muslim, than that surrounding the question of leadership after the Prophet's death. (2003, p. 70)

It should be noted that the majority of the states analysed are governed by Islamic Shar'ia. This means that governance regimes and legal frameworks are premised on Islamic jurisprudence (see Editors' preface), although there is a great deal of variety in how this is interpreted and organized with respect to state - society relations. Platteau (2010) argues that there remains an instrumentalism of Islam in political organization and development. When we take a retrospective look at the deep political history of Muslim countries, it becomes apparent that authoritarian political regimes were dominant throughout, and that in these regimes politics and religion co-existed as separate entities linked through an asymmetric relationship of mutual recognition.

Countries of the Middle East differ in their historical evolution, social composition, economic structures and state forms. All the countries are Arab except Afghanistan, Israel, Iran and Turkey. All are predominantly Muslim except Israel. All Muslim countries are predominantly Sunni except Iran and Bahrain, with Sunni and Shi'a roughly equal in Iraq. State structures, some of which are set out in Table 1.1, vary from theocratic monarchy (Saudi Arabia) to secular republic (Turkey) and Gulf states all have constitutions premised on Islamic Shar'ia. Political scientists have used various terms to describe state organization including 'radical Islamist' (Iran); 'patriarchal conservative' (Jordan and Saudi Arabia) and 'authoritarian privatizing' (Egypt and Turkey) (Moghadam 1993).

The complexities of religious affiliation and organization are shown in Table 1.2, which includes the key schools of Islamic jurisprudence in Sunni governed states and Shi'i groups in Shi'i states. The process of Islamic interpretation of the Qur'an and Hadith is called fiqh and is undertaken by clerical scholars or muttawa. Fiqh is an ongoing process and revivalist scholars have argued for interpretations to be reassessed in light of contemporary Western knowledge and sciences (Ramadan 2009). However, as the chapters will reveal, the complexity of figh illustrates ways in which language is socially constituted, as Muslim leaders can often gain affirmation of political action by recourse to widely acknowledged and respected religious scholars. 
Table 1.2 Religious affiliations in global regions and selected Middle East countries (2009 estimate) ${ }^{1}$

\begin{tabular}{|c|c|c|c|c|c|c|}
\hline \multirow{3}{*}{ Bahrain } & \multirow{3}{*}{ 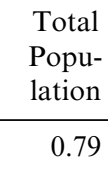 } & \multirow{2}{*}{\multicolumn{2}{|c|}{$\begin{array}{c}\text { Muslim Population } \\
\text { Total, millions }\end{array}$}} & \multicolumn{3}{|c|}{ Breakdown and Sect if available } \\
\hline & & & & Sunni & Shi ${ }^{6} i$ & Other \\
\hline & & 0.64 & 81.2 & $25 \%$ & $57 \%$ & $\begin{array}{l}\text { Christian } 9 \% \\
\text { Other } 9 \%\end{array}$ \\
\hline Egypt & 83 & 78.5 & $90^{2}$ & $89 \%$ & $<1$ & $\begin{array}{l}\text { Coptic Christian 9\% } \\
\text { Other Christian 1\% }\end{array}$ \\
\hline $\operatorname{Iran}^{2}$ & 75.1 & 73.8 & 98 & $9 \%$ & $89 \%$ & Other $2 \%$ \\
\hline Jordan & 6.5 & 6.2 & 95 & $94 \%$ & $<1$ & $\begin{array}{l}\text { Christian } 6 \% \\
\text { Other up to } 2 \% \\
\text { (reported) }\end{array}$ \\
\hline Kuwait & 3.1 & 2.8 & 90 & 70 & $20 \%$ & 10 \\
\hline Oman & 2.9 & 2.5 & 86 & $\approx 4.5 \%$ & $6.5 \%$ & Ibadi Muslim 75\% \\
\hline Qatar & 1.5 & 1.2 & 77.5 & 69.5 & 8 & $\begin{array}{l}\text { Christian } 8.5 \% \\
\text { Other } 14 \%\end{array}$ \\
\hline Saudi & 26.2 & 25 & 97 & $85 \%$ & $12 \%$ & Other $3 \%$ \\
\hline Turkey $^{2}$ & 75.7 & 74 & 98 & $86 \%$ & $12 \%$ & Other $2 \%$ \\
\hline UAE & 4.7 & 3.6 & 76 & $68 \%$ & $8 \%$ & Other $14 \%$ \\
\hline Yemen & 24.3 & 23 & 99 & $64 \%$ & $\begin{array}{l}25 \% \text { Zaydi } \\
10 \% \text { Other } \\
\text { Shi'i }\end{array}$ & Other $1 \%$ \\
\hline MENA Total & 345 & 315 & 91.2 & & & \\
\hline Asia-Pacific & 4037 & 973 & 24.1 & & & \\
\hline Other Africa & 801 & 241 & 30.1 & & & \\
\hline Europe & 731 & 38 & 5.2 & & & \\
\hline Americas & 920 & 4.6 & 0.5 & & & \\
\hline World Total & 6,860 & 1571 & 22.9 & & & \\
\hline
\end{tabular}

Notes:

1. Compiled from multiple sources including Pew Forum on Religious and Public Life 2009; Long, Reich and Gasiorowski (2011); UNDP 2010; population figures are constantly changing due to natural growth and migration and census data is often out of date. These figures are in the end a judgement on the consensus between multiple, often contradictory sources and should be used with caution. This is an area for further research.

2. Both Turkey and Iran are included in total for Asia-Pacific.

\section{Globalization, Culture and the Resurgence of Islam}

Deetz et al. (2000) have argued that globalization and changes in social relations and in the nature of products and work processes have created a crisis of control in contemporary global organizations. They cite 
issues such as increasingly professionalized workplaces, geographically dispersed facilities and turbulent world markets that have contributed to the difficulty of coordination and control. These changes signal a shift to more ambiguous leadership roles and leader-follower relations which identify that relationships are not fixed but must be negotiated (Fairclough 2007; Fairclough and Chiapello 2005; Grint 2005, 2009; Meindl 1995; Swan et al. 2009; Yukl 2008). They further challenge individualistic orientations in leadership theorizing: the self preservation, self interest and self-promotion implicit in neo-liberal conceptions of political economy and industrial growth. It is, however, important that the revision and reinterpretation of the concept and dynamic of leadership is viewed as multi-layered.

Castells' (2009) observations inject into our deliberation the connectedness of international political economy, social movements, international organizational interventions, regional state alliances, conflicts and postconflicts. The constitution of leadership as the property of a collective rather than as an individual characteristic mitigates against conventional representation of individual heroic leadership behaviours (Grint 2009, p. 2), and suggests that this quest to depart from what we term heroic social justice and ethical positions in Islamic states will be a difficult endeavour, as the following chapters will elaborate. Our discussion of Islamic leadership will show that the collective and relational orientation of a social ethic is embedded in Islamic leader-follower behaviours.

As Grint argues, the West's search for post-heroic versions of leadership closes off the 'romance' of heroic leadership (Meindl 1995). Adopting a multi-layered, multi-contextual and multi-cultural position, Grint argues that leadership scholarship: "closed off from radical alternatives not because of its relationship to capitalism, or patriarchy, or ethnicity, or any other variable, but because it is so closely related to the realm of the sacred' (2009, p. 15). Repositioning the sacred and reconfiguring its dynamic interaction with leadership political processes will ultimately assist in attaining new perspectives not generally admitted by Western epistemologies. Within Islamic states, of course, no reimagining is necessary: faith, devotion and the sacred are integral to the practice of leadership and to revealing the qualities of that leadership (Beekun and Badawi 1999).

It is important to note, however, the potential confusion between Islam as a religion and Muslim, or Arab, or other relevant cultures. A religion is usually embedded in one or more cultures, but it cannot be reduced to a single culture (Roy 2002). Although our focus is on the Middle East (as defined later in this chapter), Said (1978) argued that we should avoid equating Islamic ideology only with the territories of the Middle East, 
a concept that underpins approaches he termed 'Orientalism'. This suggests that the role of Islam in shaping contemporary societies has been overemphasized. Westernization (globalization) is a social and cultural force whatever the official ideology of certain countries has to say to the contrary.

\section{Re-Islamization and Westernization}

Islam is an all-encompassing ideology which provides the organizing structure of meaning for political, social and cultural life. Thus Islam represents religion and state, and a system of belief and law that governs both spiritual and material conditions of everyday life and, as such, is central to state formation and governance.

Islam, or re-Islamization, can be observed in personal behaviour, growth in religious practices and a return to patriarchal family structures. Esposito (2005) uses the phrase, 'Islamic resurgence'. This is described by the author as an increased emphasis on religious identity in individual and corporate life. This involves a noticeable increase in religious observance (mosque attendance, fasting during Ramadan, abstention from alcohol); a new vitality in religious literature and media broadcasting (for example, Al Jazeera); the growth of Islamic associations concerned with reform, especially women's organizations; and the reassertion of Islam in regional politics. Re-Islamization requires organizations of dedicated and trained Muslims who, by their example, call on others to challenge social injustices. Esposito (2005, p. 165) summarizes the ideological framework of Islamic revivalism as follows:

1. Islam is a total and comprehensive way of life. Religion is integral to politics, law and society.

2. The failure of Muslim societies is due to their departure from the "straight path' of Islam, and their following a Western secular path.

3. The renewal of society requires a return to Islam, an Islamic religiopolitical and social reformation role or revolution.

4. To restore God's rule and inaugurate a true Islamic social order, Westerninspired laws must be replaced by Islamic law.

5. Although the Westernization of society is condemned, modernization as such is not.

Islamization provides an alternative development model and questions dominant neoliberal understandings of modernity (Platteau 2010). The significance of this resurgence requires an understanding of how social, political and economic relations are constructed (Islam 2009). First, the condition of modernity which in the West separates religion and politics is not the only way to view development. Second, for many Muslims, Islam 
is a 'program of life' (Ahmed 1992; Esposito 2005). However, this modern resurgence in nations as widespread as Algeria and Iran was a result not of state legislation, but, on the contrary, accompanied the process of Westernization. As Roy (2002) argued: 'We tend to overemphasize the Islamic factor in the very process of Islamization, and miss all the others. Relationships between Islamization and globalization must be scrutinized more closely therefore' (p. 14).

The process of Westernization does not only include changes in economic and social relations. It also includes religiosity and a focus on increasing forms of transnational communication and knowledge exchange: global networking logic, interconnectedness, harbouring social movements and ideas concerned with ethics, moral values, professional development and personal success (Castells 2009; El Ghazili 1994). These are 'symbolising mobilisers' that bring into play new network organizations and configurations of power. The perception of a clash of civilizations between West and Middle East, and on values inherent in social and political organization, blurs the complexity of international relations. Norris and Ingleheart's 2002 treatise on the 'cultural clash' assumes a Western superiority and dominance in world order and is being challenged by social movements (Castells 2009; Bebbington 2008).

Thus, one cannot discuss religion and politics, but rather religiopolitics (Esposito 2005, p. 159). Islam is believed to be relevant and integral to politics, law, education, social life and economics. The question is not whether religion should inform life, but when and how. It is impossible to understand the salience of religion and the strength of Islamic resurgence without bringing into context decisive historical events. These include the Al Sa'ud's successful conquest of much of the Arabian peninsula and espousal of Wahhabism as state ideology, and the challenges associated with the abundance of Saudi Arabia's oil resources, a theme we explore later. This has led to an accumulation of frustration at the inadequacy of state leaders in meeting the challenge of modernization, engendered by a series of military defeats by the West (Platteau 2010, p. 256-7). To appreciate, critique, analyse and debate the nature and practice of leadership one must look at the world through an Islamic lens. There is no 'secular', and no sharply defined dichotomy between the sacred and the profane. Islamic symbols, slogans and ideology have become prominent fixtures in Muslim politics. This historical logic is affirmed by Lewis: 'The idea that any group of persons, any kind of activities, any part of human life, is in any sense outside the scope of religious law and jurisdiction is alien to Muslim thought' (2002, p. 111).

The observations of critical social theorist Grint (2009) reflect this when he states that a critique is necessary of romance leadership, both heroic 
and collaborative notions (Meindl 1995), and that we need to reconfigure the dynamic relations of the sacred in and through leadership concepts and processes, in and of the sacred as it is constituted in diverse cultures, rather than attempting to eliminate this relationship (Grint 2009, pp. 14-15).

The cross fertilization of ideas and the deterritorialization of Islam and the Middle East in an age of globalization is nicely phrased by Princess Adelah bint Abdullah of Saudi Arabia:

\footnotetext{
We should have an open mind and borrow the good from other cultures, including the West. There should be a process of a cultural give and take. Western civilization is indebted to Islam on several counts. The only thing is that we should be careful to take the good and leave the bad. Without doing that, we cannot progress. In the age of globalization, it is impossible to erect barriers. Let us take what is best in Asia, Europe, and America and use it for the healthy growth of society. (Arab News 2006)
}

Islamic revivalism, then, is a response to some aspects of Western values and development interventions that have challenged Arab knowledges and identities (Ahmed 1992; Roy 2002). Several scholars have argued that twenty-first century leadership requires a way for organizational actors and development stakeholders to re-envision their position in an era of post-industrialization and globalization (Ahmed and Donnan 1994; Grint 2005; Sinclair 2007; Western 2008). This requires a shift from the values and cultural norms of the industrial (Western) paradigm which fosters rational, control oriented, performance focused, self-interested, hierarchical structures and the expression of individualism to one that engenders collaboration, inclusiveness, commitment to human development and an ethics of care (Deetz et al. 2000; Greenleaf 1977; Grint 2007, 2009). A critical interpretative view of Islamic leadership challenges neoliberal models since behaviour orientation focuses on social change, emancipation and humanistic development (Ahmed 1992; Chapra 1993; Choudhury 1993; Platteau 2008).

\section{LEADERSHIP: CONTEMPORARY DEVELOPMENTS IN WESTERN LEADERSHIP THEORIZING}

A vital issue to be addressed in a critical review of leadership development in the Middle East is that current scholarship is still largely premised on Western constructions of leadership identities, relationships and behaviours (Metcalfe 2010; Syed 2010; Syed and Ali 2011), and this is reflected in much social science scholarship (Storey 2004). As the authors in this volume will elaborate, few scholars have paid attention to the importance 
of history, national identity, extensive governance reforms across the region and - especially relevant to our studies here - the terrain of international relations over the last three decades. The Iran-Iraq war, Iraq's invasion of Kuwait, the events of 11 September 2001 and the bombings of Madrid and London, the US-led invasions of Iraq and Afghanistan, the attack on the USS Cole in Aden harbour, coupled with economic turbulence and ongoing uncertainties in state leadership succession and the varying degrees to which religion influences social and organizational relations: all are components of cultural inquiry that have been underemphasized by recent scholarship which has therefore presented only a partial picture of Middle East leadership (Halliday 2010; UNDP 2010).

The Western conception of leadership incorporates myriad culturally specific assumptions, from democratic state leadership to a free market, capitalist structure for business. As Dunning (2007) has argued, modern capitalism has failed on at least three basic dimensions: failure of markets, failure of institutions, and failure of moral virtues. In response to this, Western writers have attempted to build an understanding of leadership that includes as a subset ethical principles such as trust, trustworthiness and cooperativeness. This values-based leadership promotes ethical and moral behaviour so as to advance human wellbeing for all organization actors. Attention has been placed on the inner qualities of ethical values as well as the representation of organization leaders themselves as embodying the ethical codes that they have internalized. This helps to build and sustain trust behaviours in organization relations, as well as associated networks (Ciulla 1995, 2005). This is, however, premised on the development of organizational competitiveness through ethical practices, not on wholesale ethical and economic rejuvenation of societies (Chapra 1992; El Ghazali 1994; Platteau 2008; Wilson 1985).

As we will go on to show, the organization leader is only one part of a social system. A clear difference between Western and Middle Eastern states is the latter's belief in integration via umma (El Ghazali 1994). The Islamic community is inextricably connected. Conceptualizations of leadership are thus wholly different when examining society through an Islamic lens, since there is no secular alternative (Metcalfe 2010; Metcalfe and Rees 2010). Leaders in Islamic states regard responsibilities as encompassing social, organizational and community-oriented responsibilities.

\section{Leadership Theorizing: A Brief History}

Figure 1.1 provides a diagrammatic overview of the historical development of leadership theorizing. Traditional leadership studies reflected assumptions about leadership in the post World War II period in the US. 
Period

Theories

Principles

Scholar (Year)

1930<smiles>C1=CCCC1</smiles>

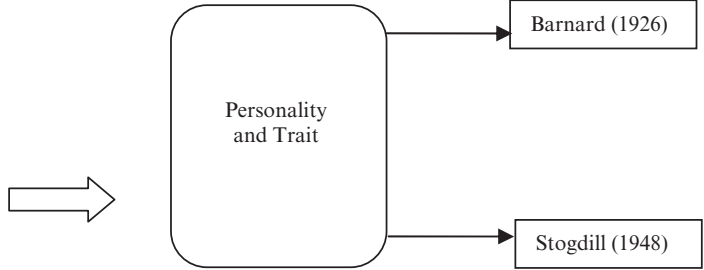

and Trait

Barnard (1926)

1950

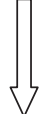

1960<smiles>C=[Tl]</smiles>

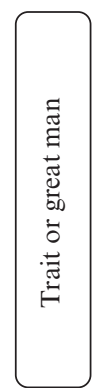

1970<smiles>C1=CCC1</smiles>

1980

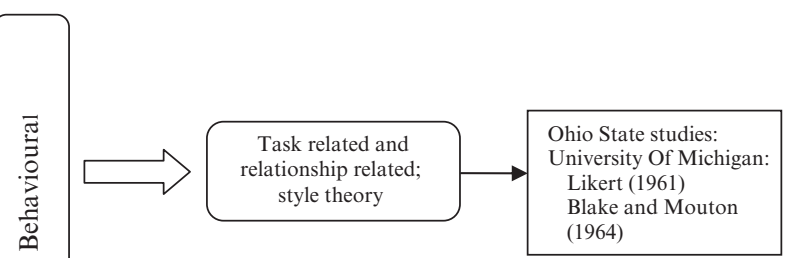

$\sqrt{1}$

1990

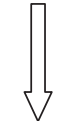

2000
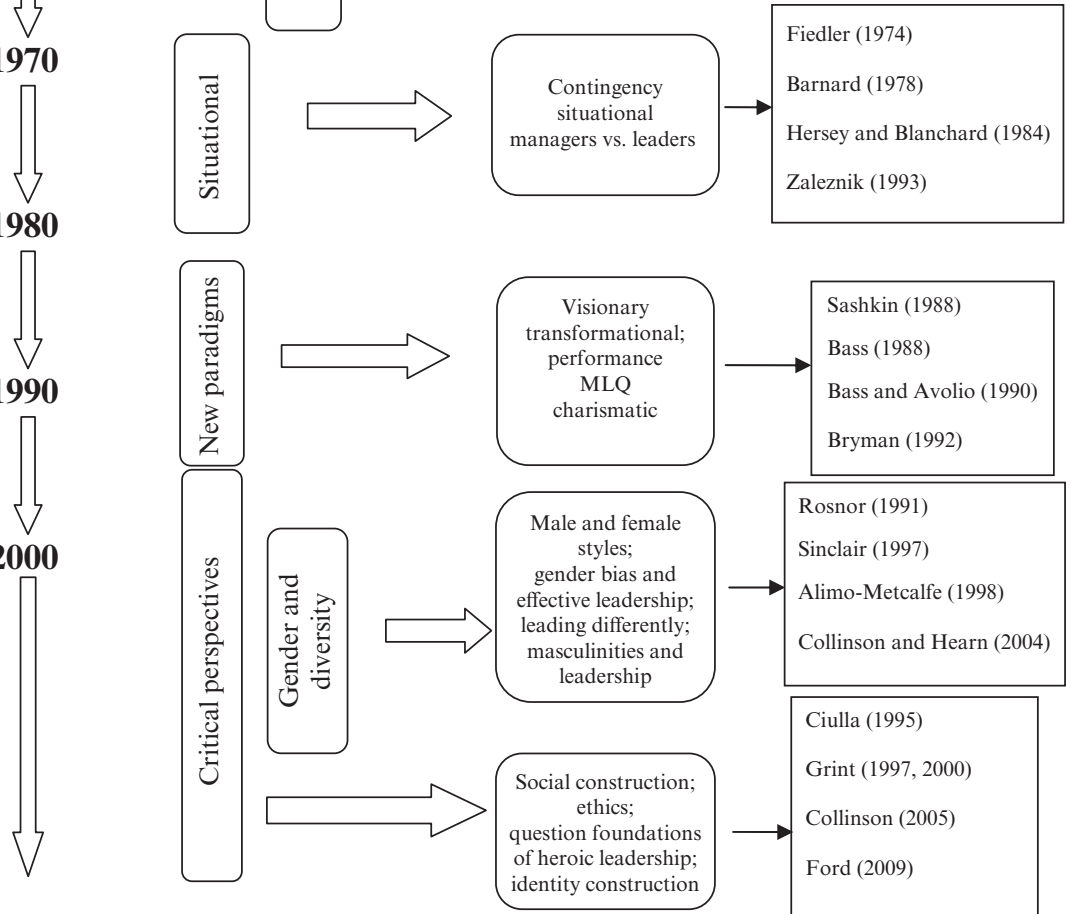

styles;

Rosnor (1991)

Sinclair (1997)

Alimo-Metcalfe (1998)

Collinson and Hearn (2004)

Figure 1.1 Historical development of leadership theory 
Barnard (1938) argued initially that there is no single form of leadership. Behavioural psychologists, principally Stogdill (1950) and his team of researchers at Ohio State University, focused on 'trait' approaches that characterized leadership competencies such as intelligence, dominance, control orientation, task focus, objectivity and so on. Later in the 1950s, psychologists investigating leadership shifted their attention to 'behaviours'. Scholars, again at Ohio State University, measured behaviours via questionnaires and tended to focus on two dimensions: a 'concern for task' and a 'concern for people undertaking the task'. They identified behaviours termed 'consideration' and 'initiating structure' which correlated positively with employee satisfaction (Fleishman 1953, Stogdill 1974 in Alimo-Metcalfe 1998). Subsequent scholars paid more attention to context. Fiedler's contingency approach reflected developments in other social sciences where organization leadership was determined by strategy (Chandler 1962) and technology (Woodward 1970; see also Grint 1997, pp. 83-85).

The later 1970s and early 1980s marked a watershed in the history of leadership studies since the situation and contingency models, whilst including the complex context situations of leadership practice, provided little advice as to how to approach leadership in an era of economic volatility and significant social and economic change. It was in this environment that new leadership paradigms emerged. This new paradigm (Bryman 1992) encompassed visionary (Sashkin 1988), transformational and transactional approaches (see Bass and Avolio 1990, 1994). This reignited concerns for work productivity and human relationships. These were not necessarily at opposing poles. Zaleznik (1992) argued that there was a clear distinction between leaders and managers and that transactional approaches were about coordination, control and organization: in essence a management function. While these activities are not significantly associated with leaders, transformational techniques encourage trusting behaviours (idealized influence), motivate and enthuse (inspirational motivation), challenge employees (intellectual stimulation), and build meaningful relationships (individual consideration) (Bass and Avolio 1994).

Critical perspectives, which emerged in the early 1980s, include a broad range of approaches that challenged epistemological frames and questioned grand narratives of leadership, whom they benefited and for whom they were written (Utting 2006). Importantly, however, they were underwritten by Western-based knowledges. Gender and feminist critiques helped to stress how leadership theorizing was premised on masculinized constructions of knowledge (Calas and Smirchich 1991; Collinson and Hearn, 2004; Sinclair 2005, 2007). Critical perspectives highlighted the 
importance of the social construction of knowledge, power relations in leader-follower interactions and, importantly, the way in which language meaning is socially and culturally variable (Sinclair 2007).

Although not the first to broaden critical investigations, J.M. Burns was typical: 'Leadership over human beings is exercised when certain motives and purposes mobilise, in competition or conflict with others, institutional, political, and other resources so as to arouse, engage and satisfy the motives of the followers' (Burns 1978, p. 18).

To Burns, leaders are a particular kind of power holder. While acknowledging the importance of power, some scholars stressed effectiveness. De Vries, for example (1994, in Grint 1997), noted that 'effective leadership' depends on the complex patterns of interactions and relationships among leaders and followers, and importantly the situational and cultural context. For de Vries (1994), effective leaders are very good at 'building alliances' and creating commitment so that others will share (and accept our insertion) their 'vision' (see also Yukl 2008).

Grint's review of the historical formation of leadership theorizing is interesting, as he suggested that contingency approaches and relationships between leaders and followers had been part of the original thinking of Barnard. Grint highlights how leaders need to be aware of, have empathy with, and understand the goals and orientations of the workers. Barnard concluded that informal relations and informal authority were important skills which the leader needed to nurture to ensure the cooperation and trust of followers:

The followers make the leader, though the latter also may effect and guide the followers. Barnard, in Grint (1997, p. 85)

The dynamics of leader-follower relations, and the psychological makeup of all involved, have become central to understanding effective leadership behaviours, superseding earlier schools of belief in a universal theory of leadership (Storey 2004). Critical leadership studies have also shown the necessity of exploring language, cultural context and social interaction amongst leaders and followers and how they help constitute and reconstitute fluid and dynamic identities.

This brief overview of the historical foundation of leadership knowledge is relevant to understanding the socio-cultural dynamic of leadership behaviours in the Middle East since, as we will show, even early accounts of the interactions of the Prophet Muhammad and early caliphs with their followers presented leadership as a relational and group activity, enacted through a mutual commitment to a social ethics of humanistic development, and required trust behaviours (Al-Attas 1995; Noor 1999). 


\section{The GLOBE Leadership Study}

As already highlighted, the dominant leadership writings are premised on Western values and norms and have largely examined states that are developed rather than developing. This is also the case in the growth of cross-cultural writings on leadership. Indeed, Western scholars have seemingly given precedence to some geographic regions over others. While scholarship on Asia and transition states is now expansive, there is a dearth of organization and management literature on the Middle East, Africa and Latin America (Metcalfe 2010; Metcalfe and Rees 2010). An exception is the GLOBE Leadership Study, which focused on values and practices as well as leadership attributes in 61 nations. National cultures were examined in terms of nine dimensions: performance orientation, future orientation, assertiveness, power distance, humane orientation, institutional collectivism, in-group collectivism, uncertainty avoidance and gender egalitarianism (House et al. 2004). The first six dimensions had their origins in the landmark study of Hofstede (1980, 1983). The overall goal of GLOBE was to examine the effect of specific cultural variables on leadership and organizational processes in order to discern any underlying patterns prevalent in specific socio-cultural contexts. However, there is also critique that attests to the differentiation in norms and values, both ideologically and structurally, and especially over time. Fifty-four researchers from 38 countries agreed a universal definition of leadership: 'the ability of an individual to influence, motivate and enable others to contribute towards the effectiveness and success of organizations of which they are members' (House et al. 2004, p. 5). The research team could not agree a definition of culture, however.

The GLOBE project specifically determined its parameters as the organization and not leadership in general. Four countries from the Middle East were included in the study: Iran, Kuwait, Turkey and Qatar, two of which are discussed in detail in this volume. Hofstede, in an attempt to assign regional countries to a cluster in what he termed the Near East, grouped together Egypt, Lebanon, Libya, Kuwait, Iraq, Saudi Arabia and the United Arab Emirates, based on his own research. He analysed them in terms of: (1) power distance and individualism; (2) power distance and uncertainty; and (3) uncertainty avoidance and masculine scales.

In the power distance and individualism matrix, Iran and Turkey represented high power distance and low individualism cultures. This displays an orientation to accept one's place in a hierarchy and be committed to broader community and group goals. In addition to a strong collectivist character, all displayed strong uncertainty avoidance and masculine characteristics (Hofstede 2003; Kabaskal and Dastmalchian 2001). 
Recent political conflicts in Tunisia, Egypt and Libya attest to the ways in which cultural values and ideologies evolve and change in relation to social and economic relations. These observations are significant in providing an overview of shared cultural meanings and norms, but do little to expand the specificities and nuances of the myriad stages of development, governance and political institutions and gender relations, as well as the different state formations and social practices associated with Islam in daily life, and its association - or not - with individual Islamic national regimes. This is all the more significant when House et al. (2004) argue that their focus is on institutional leadership. In our view this represents an Anglocentric view of leadership roles and relations, as the varied discussions on leadership in this volume clearly demonstrate.

\section{Ethics in Leadership}

A key aspect of critical scholarship relevant to an examination of Middle East leadership is the nature of ethics in shaping leadership behaviours. The ethos of leadership varies fundamentally across nation states. How a particular society perceives and constructs leadership needs to be understood and debated in context. For example, Fairclough (2007), drawing on a Weberian analysis of formal rationality and substantive rationality, details the impact of what he terms 'ideational systems' (cultural, religious and political) on social institutions. A key observation was that the educational institutional framework laid the greatest impact on conceptualizations of leadership.

The focus on knowledge is significant. 'Leaders' and the 'led' participate in social and organizational interaction informed by their ideological and cultural knowledge, transmitted from generation to generation and learned through families and communities, a phenomenon explained by Bourdieu and Passerson (1977) as 'habitus' (Bebbington 2008). As different cultures, societies and communities construct leadership in diverse ways, the need to explore these social constructions becomes highly relevant in multi-cultural and international contexts (Javidan et al. 2006).

Doh and Strumph (2005, p. 15) devised a model of responsible leadership and governance as shown in Figure 1.2. They argue: 'Many companies are pursuing a mission of responsible leadership and governance ... responsible leadership and governance are morally preferable to alternative approaches to management and oversight and economically beneficial to the companies and organizations that adopt it' (p. 15).

While advocating a humanistic commitment to leadership, underpinning their logic is still a neoliberal performative notion, illustrated by 


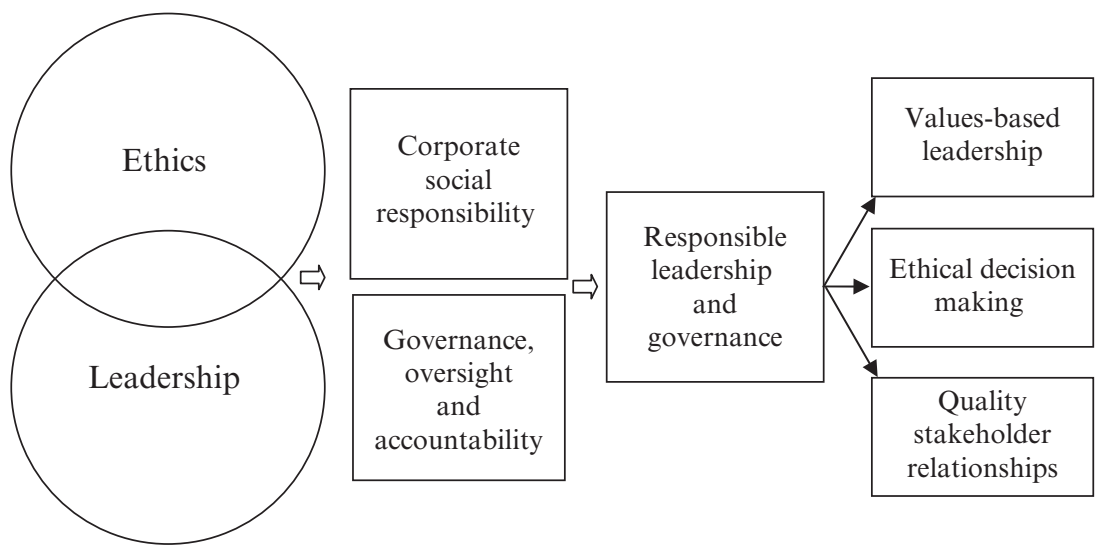

Source: Doh and Stumpf (2005), Handbook on Responsible Leadership And Governance in Global Business, p. 15.

Figure 1.2 A framework of responsible leadership and governance: antecedents, construct and behaviours

their focus on economic benefits. The observed behaviours - valuesbased-leadership, ethical-based decision making and quality stakeholder relationships - represent, it could be argued, the commoditization and objectification of a global business ethic to preserve and promote organization competitiveness. What is lacking in this model is a linkage to the social system that the organizations are part of, and a determination of who evaluates outcomes, and what the measures are for evaluating the ethical behaviours observed.

Maak extends the ideas of responsible and ethical leadership by bringing 'such vision to life by mobilizing stakeholders inside and outside the organization to contribute to business sustainability and legitimacy' (2007, p. 34). This vision is formed through social interaction and relies on commitment to build social capital through trust behaviours and relations (Bourdieu and Passeron 2007). Citing Balkundi and Kilduff, he states: 'To a considerable extent, organizations and environments exist as cognitions in the minds of leaders and followers' (our italics) (2005, p. 946, in Maak 2007, p. 334).

Maak further posits that the building of social capital by leaders, through organization networks and social ties, can benefit all stakeholders 


\section{Social capital}

\begin{tabular}{|c|c|c|c|c|}
\hline & & $\begin{array}{l}\text { Network } \\
\text { organization }\end{array}$ & $\begin{array}{l}\text { Shared } \\
\text { discourses/ } \\
\text { language }\end{array}$ & $\begin{array}{l}\text { Relational } \\
\text { dynamics }\end{array}$ \\
\hline \multirow{7}{*}{\multicolumn{2}{|c|}{$\begin{array}{l}\text { Shaped by } \\
\text { economic, } \\
\text { geopolitical, } \\
\text { institutional and } \\
\text { governance } \\
\text { context }\end{array}$}} & \multicolumn{3}{|c|}{1} \\
\hline & & \multirow{4}{*}{\multicolumn{3}{|c|}{$\begin{array}{l}\text { Organization and representation of leadership and } \\
\text { social capital } \\
\text { Normalization of social values and ethics } \\
\text { Valuing trust relationships and ethical leadership } \\
\text { behaviours } \\
\text { Inter- and intra-competence of organization actors } \\
\text { and network stakeholders in social system } \\
\text { Symbolic representation of ethics in leadership } \\
\text { behaviours } \\
\text { Cultural capital manifested in dynamic stakeholder } \\
\text { relations }\end{array}$}} \\
\hline & & & & \\
\hline & & & & \\
\hline & & & & \\
\hline & & \multicolumn{3}{|c|}{$\downarrow$} \\
\hline & & \multicolumn{3}{|c|}{$\begin{array}{l}\text { Responsible leadership: } \\
\text { How to measure? } \\
\text { Benefits of responsible leadership? } \\
\text { Individualistic orientations }\end{array}$} \\
\hline
\end{tabular}

Source: Maak (2007); Bourdieu (2001).

\section{Figure 1.3 Social capital and responsible leadership}

and bring about responsible, or transformational, leadership (see also Burns 1978). The 'humble networker' (Maak 2007, p. 340) is still, however, the weaver of 'value networks' (Maak 2007, p. 339) aiming to contribute to both sustainable business and a common good. A model of responsible leadership and social capital is shown in Figure 1.3. Our concern is that this leadership ethic is often constituted in neo-liberal market environments where social and ethical intelligence is about value creation for organization systems, not societies themselves. Specifically, if 
responsible leadership is embedded in organization behaviours, how can one check which ethics embrace the social good as opposed to individual orientations? Also, as already touched on, how are stakeholder orientations inside and outside the organization, in diverse geopolitical and governance regimes, measured and evaluated - and by whom? (Ciulla 2005; Chapra 1993).

In the next section, we address how stakeholder social capital can be constructed as a means of enhancing all human livelihoods and wellbeing. We explore what is meant by leadership in an Islamic context and draw on contemporary scholarship to elucidate the similarities and differences in leadership behaviour.

\section{LEADERSHIP: AN ISLAMIC LENS}

\section{Islamic Resurgence and State Formation}

We discussed previously the processes of globalization, Islamization and Islamic resurgence. The vision of Islam as a revealed religion is to achieve the wellbeing (falah) of men and women and to establish an environment and civilization in which all can live in peace and harmony. This is achieved through a process of continued development governed by shar'ia, ethics and morality. If the objectives of shar'ia, are realized, then falah is also realized. These objectives are aptly summarized by Muslim scholar Imam Hamid al-Ghazali:

The objectives of the Shariah is the well-being of the people, which lies in safeguarding their faith (din), their self (nafs), their intellect (aql), their posterity (nasl) and their wealth (mal). Whatever ensures the safeguard of these five principles serves public interest and is desirable, and whatever hurts them is against public interest and its removal is desirable. (Al-Ghazali, in Ahmad 1995)

As Chapra observed (1993), revivalism has led to the ideologization of Islam. Instrumentalism in political Islam need not be an impediment to development, but the interwoven nature of Islam and governance adds complexities not configured in Western accounts. All the countries of the Middle East and North Africa, for example, score comparatively low in measures of public accountability, quality of public administration and the efficiency of state bureaucracy (Platteau 2010). This means that Islam has impacted the organization of the political arena more than the economic, but current Islamic constitutions have economic ambitions premised on Islamic shar'ia and jurisprudence.

Islam is an all-encompassing ideology which provides the organizing 
structure of meaning for political, social and cultural life. Thus, Islam represents religion and state, and a system of belief and law that governs both the spiritual and material conditions of everyday life. Islam is thus central to state formation and governance. As Table 1.1 indicates, Islamic states are not homogeneous and include regimes that operate with a theocratic establishment and state supported clerical leaders as well as monarchs and elected presidents.

\section{Defining Leadership within an Islamic Framework}

Leadership in Islam is a trust (amanah). It represents a psychological contract in which the leader commits to try his best to guide his followers, to protect them and to treat them justly. Hence the leadership process in Islamic communities is concerned with social welfare and moral justice as well as with attaining economic development goals. Sahih Bukhari, an eminent Islamic scholar, cites a hadith that all Muslims are the: 'shepherd of a flock and hold leadership positions' (Bukhari, in Beekun and Badawi 1999). Beekun and Badawi argued as early as 1999 that ethics will be a defining feature of the way leaders are judged and evaluated. This has been precipitated by the rise of religiosity worldwide (Norris and Ingleheart 2002), the growth of ethical codes and global conventions such as the UN social compact and a response to specific organization malpractices (for example Enron) as well as the multitude of humanitarian injustices committed by transnational corporations in developing nations, including exploitation of workers, denial of basic human needs and rights, sexual exploitation and contribution to environmental degradation (Pearson 2007; UNDP 2009a).

According to Islam, leaders have two primary functions: as servant leaders and as guardian leaders. Leaders are servants of their followers and leadership through service is embraced in a hadith: 'A ruler who has been entrusted with the affairs of Muslims, but makes no endeavour for their material and moral uplift and is not merely concerned for their welfare will not enter paradise with them' (reported by Abu Malih in Sahih Muslim 1:82, Chapter 44, Hadith no. 264).

The idea of leader as servant is embedded in Islamic philosophy and was more recently adopted by Greenleaf (1977). The guardian leader has a role in protecting his community against tyranny and oppression, in encouraging taqwa (duty and responsibility) and in promoting justice. A leader embraces natural feelings of wanting to lead, and then from the leader's conscience arises the aspiration to lead justly (Sarayrah 2004).

The characteristics of the servant leader as codified by Larry Spears include the following: 
Listening: leader seeks to identify different points of view and listens receptively to what is 'said and 'unsaid'.

Empathy: strives to promote empathy in order to help legitimize his or her role/special gift of serving.

Healing: healing of relationships is a powerful force for social transformation.

Awareness: self-awareness and critical reflection strengthens understandings of ethics power and values.

Persuasion: a process of convincing rather than coercion is seen as appropriate for negotiations and building trust behaviours.

Conceptualization: servant leaders need critical judgement and analytical reasoning to seek a balance between concepts and practical action. Foresight: have insights into the realities of the present, reflections on the past, and potentialities of the future.

Stewardship: a strong commitment to the service of others.

Commitment: to the growth of every individual and organization.

Building Community: building alliances between individuals, organizations and public and international institutions to engender community of care and ethics to prosper.

Spears 2000, quoted in Sarayrah 2004, pp. 63-64

\section{A Model of Islamic Leadership}

According to Beekun and Badawi (1999) leadership is rooted in belief and willing submission to the creator, Allah. The key task of leaders is to do good deeds and work towards the establishment of Allah's din. This involves attempting to sustain social cohesiveness while also exemplifying openness, willingness to learn and reflect and showing compassion to subordinates. Beekun and Badawi's model of the moral bases of Islamic leadership is shown in Figure 1.4.

The definitions of the terms used in Figure 1.4 are as follows:

Iman: the core of the moral character is Iman or faith in Allah. A belief in oneness of Allah (tawhid).

Islam: the term Islam comes from the Arabic root slm meaning peace and submission. Islam means peace with Allah, with oneself and willing submission to Him.

Taqwa: an inner consciousness of one's duty toward Allah and an awareness of one's accountability.

Ihsan: love of Allah. Ihsan embraces the attainment of personal qualities associated with self-actualization and completeness. This includes characteristics such as sabr (patience), ubudiyqah (servitude), shukr 


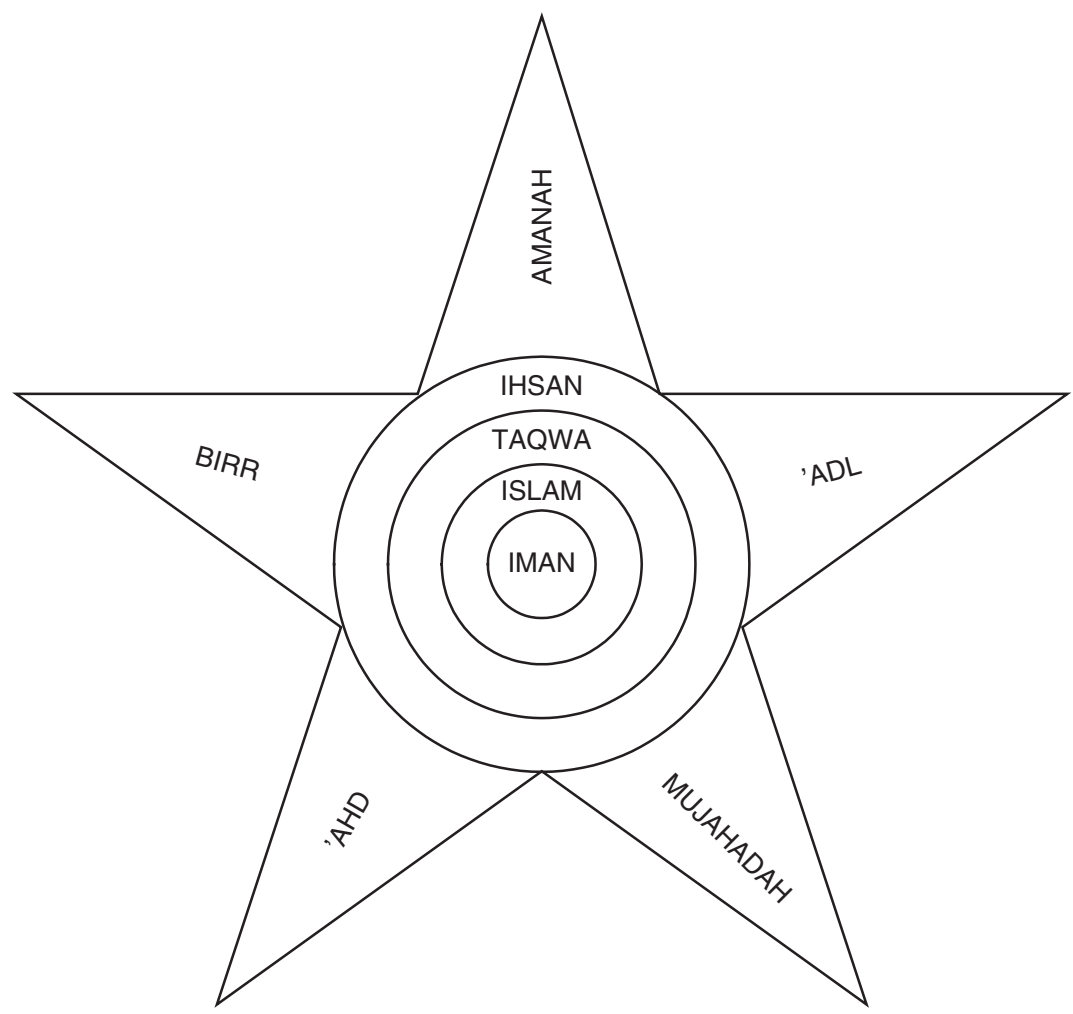

Source: Beekun and Badawi 1999, p. 15.

\section{Figure 1.4 Moral bases of Islamic leadership}

(thankfulness), jihad (struggle) and ijz (humility) (Zaman and Asutay 2009).

Adl: balance and harmony. Organization and social relations should be configured to maintain stability and complement the unique qualities of men and women. It is a dynamic characteristic that each Muslim must strive to develop, whether he is a leader or a follower (see Umar-ud-Din 1991).

Mujahadah: concerned with struggle within oneself for self improvement. Embraces self-reflection about one's leadership practice.

'Ahd: integrity and keeping one's word.

Amanah: trust and responsibility towards stakeholders. Individuals should speak the truth, keep one's promise, fulfil one's trust. Practice modesty and behave justly (Qur'an, sura Joseph (Yusuf), 12:54-55). 
Birr: righteousness (goodness), or keeping one's word: 'Goodness does not consist in turning your face towards East or West. The truly good are those who believe in God and the Last Day, in the angels, the Scripture, and the prophets. .' (Qur'an, sura Al Baqara (2:177)

It is worth expanding upon birr and its application to leadership. The following significant attributes of leaders derive from birr:

- They act justly and do not allow their personal feelings to hinder justice.

- They have Iman since they believe in Allah, the Last Day, the angels, the Books and the messengers.

- They take care of those in need, and do so for the love of Allah.

- They are steadfast in prayer and practice charity.

- They observe all contracts, and.

- They are patient no matter what type of adversity or personal suffering they may be experiencing.

Beekun and Badawi 1999, pp. 30-31

Similar to Beekun and Badawi, Noor (1999) is among the first modern Muslim management writers who proposed an integrated model for organizational effectiveness based on the Prophet Muhammad's leadership style and interaction with his followers. The major dimensions of this theory are: (1) alignment, which takes its roots from tawhid (oneness of God), and thus inspires a sense of social mission; (2) attunement to the systemic purpose and mission, which incorporates the shared communal values such as commitment, trust, mutual respect and working for the overall advancement of society and individuals; (3) empowerment, or enablement, which induces the leader with more responsibility and accountability for the community, thus embodying the role of the vicegerent (khalifah) of God on earth. When all these three elements have been addressed, then we have al-falah, which gives synergy - the total convergence of the elements into a symbiotic whole. Synergy entails the attainment of success and prosperity for all who share the common vision of greatness (Noor 1999, p. 3).

Building on these insights, we argue that the social ethics and relational dynamic is imperative to effective leader-follower interactions. Islamic scholarship on leadership is labelled 'purposeful' (Al Attas 1995; Al-Omar 1999; Al-Faruqi 1982). 'Purposeful' is used in the sense that it has genuine intent in terms of tawhid, understanding the oneness of creator and human beings, and understanding the responsibility of humanity as Allah's vicegerents on earth. Leadership in Islam, therefore, is a relational social 
practice, a process of interaction between leaders and followers which should be based on mutual engagement and trust. In this way, business leaders can be seen as corporate khalifah, who are not only responsible for the growth of their businesses, but are also accountable to God for their actions as leaders. The principle of maslahah (concern for the public good and welfare) governs actions and behaviours of leaders and followers. Therefore, instead of typical aggressive, ego-centric, personal-interest oriented leaders, more humane and ethical conduct is expected from leaders in Islam who are tasked with serving the public good. This is a holistic view of leadership which is concerned with the moral growth and development of individuals, organizations and societies

\section{Purposeful Leadership, Knowledge and Becoming}

From an Islamic perspective, 'leading' has a strong connotation of leading toward knowledge and righteousness through words and acts, entailing a knowledge figurehead for the leader, as well as perceiving him or her as a role model in a holistic sense. The role of leadership as engaged in knowledge building, and in guiding individuals to rise to higher levels (Qur'an, sura Ripped Apart, 84:19), reflects concern with a 'process of becoming' (Choudhury 1993, p. 6; Beekun and Badawi 1999), a learning journey achieved through jihad (struggle) and an acknowledgement of the sacred (Grint 2009). In developing purposeful knowledge, a purposeful leader also requires 'systemic environment insight' (Al-Faruqi 2000). This involves self-awareness and self-assessment - the process of mujahadah (critical self-reflection: Metcalfe 2008). However, in building trust relations and working towards balance and harmony $(a d l)$, a leader needs to build the capacities of his/her followers. Islamic scholars argue that a fundamental work ethic consists in feedback being 'a gift' to be reflected and acted upon (Al-Omar 1999). Purposeful feedback helps employees learn from their mistakes and improve their productivity: lack of feedback can build tension and conflict. Destructive behaviour such as that represented by cultural masculinism when giving feedback, or succumbing to one's ego, are primary causes of leadership derailment. If trust behaviours are developed through shura (consultation), there is respect and honour for those with authority: ' . . pardon them and ask forgiveness for them. Consult with them about matters, then, when you have decided on a course of action, put your trust in God' (Qur'an, sura The Family of 'Imran, 3:159).

Consultation is extremely important in Islamic communities, as seeking knowledge has a collective dimension: each individual is responsible for sharing and dissemination. This process incorporates building the umma 
(community) and local or national Muslim societies and communities. Thus, institutional leadership (whether religious or organizational) continues to involve more than organizational management, it also includes a moral obligation for the holistic development of the leaders and followers of the community. Purposeful leadership is thus holistic, and about 'becoming', as it is concerned with the moral growth and development of individuals, organizations, communities and states. Leadership without a holistic purpose is at best a demonstration of the deployment of interpersonal and intrapersonal qualities to manage social and organizational change (Al Faru 1982). However, an effective leader in the Islamic sense is firmly grounded in a strong ethical foundation that guides all his or her activities and thinking. Human beings are managing life in its totality, fully aware that while there are ongoing challenges which require reflection, there are also constants such as a humanity's value system. As previously stated, Islam is a programme of life (Ahmed 1992) requiring commitment to lifelong learning and umma, with a responsibility to improve both material and moral wealth. The worldview represented by Islam is: 'A vision of reality and truth that appears before our mind's eye revealing what existence is all about; for it is the world of existence in its totality that Islam is projecting' (Al-Attas 1995, p. 7). Thus, every member of the community is a leader and a guardian in his or her local context. The sense of responsibility and accountability is a shared one. In the Prophet's words: 'Each one of you is a guardian, and each one of you will be asked about his subjects; a man is a guardian over the members of his household and he will be asked about his family members; a woman is a guardian over the members of her family.... Each one of you is a guardian and each one of you will be asked about his subjects' (Al-Omari 2005).

\section{Comparison with Western Leadership Ethics}

Similarities with Maak's responsible leadership model (2007) are striking. The development of organization social networks, a concern for social justice and broader social development agendas, community building and stakeholder involvement - are all involved in achieving advances in human and social development. Woolcock (1998) and Bebbington (2008) are more critical of international political relations and question the power dynamics of social capital in the global world order (also central to Bourdieu's thesis) and how institutions, whether TNCs or international organizations, yield control and exercise power.

Monitoring and evaluation of ethical leadership behaviour seems to have little influence if not accompanied by legislative measures. 'Big ego' type leaders abound in the global leadership literature (whether in the US, 
UK, Russia or China; Maak 2007, p. 340), as represented by corporate scandals contained within the ongoing global financial crisis. To make the point of trans-cultural miscommunication, when Maak states (quoting Plato) 'leaders are not shepherds' (a fundamental metaphor in understanding the role and responsibility of a leader in Islam) but weavers who weave together different stakeholders in a coalition and brokers of social capital. This could be read just as well as a 'good deal maker' in the UK or US. The politics and power of social capital is not deliberated in Maak's concept, but is central to understanding international power relations and diplomacy. Unequal power relations are also a general concern amongst intelligentsia and statesmen in MENA territories (Metcalfe and Rees 2010; Utting 2006), but unlike Western states, umma and religious codes act as regulators of individual and, ultimately, organizational behaviour.

However, as Ahmed (1992) and Roy (2002) note, globalization, the internationalization of technology and economic universalism are drawing the world closer (Castells 2009) and smoothing out many differences in diverse fields of human activity. As previously highlighted, Muslim identity and the impact of ideational systems are especially important in spite of modernization and 'meta narratives' of democracy, equality and social justice (Metcalfe 2010). Cultural fluidity and exchanges in value systems have re-ignited the politicization of Islamic identity. As previously discussed, Ahmed (1992) attributes this escalation to the revival of the religious in the modern world (see also Esposito 2005). A consequence is for Muslims to highlight their commitment to religious identity. The growth in Islamic revivalism is being expressed in national systems of education and curriculum planning. For example, the first aim of Pakistan's National Education Policy (1998-2010) is 'Within the context of Islamic perception, education is an instrument for developing the attitudes of individuals in accordance with the values of righteousness to help build a sound Islamic society' (Shah 2006, p. 372). Similarly, as highlighted when discussing state formation, the constitutions in Islamic states are explicit in upholding principles of Islamic shar'ia and in maintaining a commitment to Arabic and Persian heritage and legacy (Metcalfe 2010). Arabic scholars of leadership are concerned that waves of globalization and the intersecting flows of norms, values and practices across cultures are acting as 'disengagement' practices (Ramadan 2009) and potentially distorting the value of leadership behaviours and traditions, which are principally about the passion to motivate and nurture human wellbeing, sustainability and profitability in their communities. While ethical dilemmas concerning Western leadership practices have been broadcast widely in the media, little has been said of instances of labour trafficking and the poor treatment of migrants in GCC states and how this is influenced by globalization and this is an area for 
future inquiry (but see for exceptions Metcalfe 2010; Platteau 2010). As we have argued previously, a model of leadership that is culturally sensitive and appropriate is necessary in order to resist Westernization values that undermine Islamic governance regimes.

Our critique suggests that models of Islamic leadership are necessary a parts of a corrective and resistance strategy to Westernization processes, and Western leadership discourses that undermine Islamic governance regimes and thus cultural diversity (for example in Pakistan, Iran, Iraq, Saudi Arabia and Egypt; Grint 2009). Islamic leadership models also offer alternatives to the styles of economic governance and public administration favoured in Western states (see Chapra 1993, Choudhrey 1990).

Our aim in this section was not to merely restate myriad leadership theories, but rather open up communication and dialogue and thereby reinterpret and reintegrate the knowledge territories of East and West, the Global North and Global South (Ramadan 2009; Morgan 2007). Leadership theorizing needs to acknowledge the fluidity of ethical principles beyond those applied to neo-liberal governance regimes and to recognize that a flow of knowledge from the Global South to the Global North can offer new tools of thinking about the ethics of leadership behaviours (see Campbell 2008; Maak and Pless 2009). Ramadan argues for a liberation of ethics that can assist transnational reform toward enlightened leadership. He argues that Islamic ethics requires reflection about meaning and coherence and calls for 'dialogues':

with one's own and with other civilizations, and be apt to tackle the respective inconsistencies of practice rather than ethereal ideals or theories. Goals and ethics train the heart to the intensity of questioning and the mind to build bridges - between self and self, oneself and others, values and behaviours, and means and ends. (Ramadan 2009, pp. 312-13)

\section{THE MIDDLE EAST AND INTERNATIONAL RELATIONS: DEFINING THE TERRITORY}

The large body of criticism by international leadership scholars (for example House et al. 2004; Western 2008; Yuk1 2008) has tended to ignore the social and historical formations of state society relations, identity and political ideology. To step back and glimpse the complexities of Middle East social relations and national and international relations in the political economy is an approach that requires what Halliday termed 'a subtle mind, freed of modernist hubris' (Halliday 2010, p. 2). He proposed the prevalence of a religious discourse in all human activity. As previously 
highlighted, unlike modernist accounts of social change and transformation in the West, in the Middle East there is no secular lens.

A central tenet of this book is the influence of Islam in shaping political and governance systems and, consequently, leadership behaviour and relations. It is important to highlight the changing contours of territories allied to Islamic regimes and identities (Ali 2005). In the discussion above, we provided an overview of contemporary Islamic leadership theory. In support of this analysis, we present interpretations of leadership behaviours, relations and practices by mapping schools of Islamic jurisprudence (see Preface) and how they are bound to the geography of the region. Such ties are inexact, since migration and conflict have continuously altered allegiances, yet there are generalizations that can be observed between geographic territories. This identification with space and place, Islamic governance and ideology provides a backdrop to how historical connections between time, place, identity and Islamic affiliation are interwoven and continually interactive.

In Figure 1.5 we give a representation of the Sunni and Shi' $i$ schools and their associated branches, as discussed in the Editors' preface, and identify the nations in which the various sects and schools are dominant. In Table 1.2 we provide a breakdown of the religious affiliations of the populations in selected countries of the Middle East. The data presented is in part estimated, as religious affiliations are often ignored or assumed in censuses: in particular, accurate statistics are often unavailable for minorities, which may be misreported by individuals or merely assumed into the majority figure (Pew Research Center 2009) and members of migrant populations are often reluctant to participate in the census. This geographic mapping illustrates the complexities of regional and Islamic populations and illustrates diversity rather than homogeneity.

\section{Defining Middle East Territories}

The contemporary Middle East is portrayed as a mysterious 'other', separate and distinct from the dominant cultural associations of space, place, values and identities attached to the West in the global political economy (Halliday 2000, 2010; Said 1978) and currently associated with intrigue and conflict, with the origination and propagation of terrorism, with religious extremism and non-democratic government (Norris and Ingleheart 2002).

In this section, in order to elucidate some of the complexities of these relationships, we discuss the Western construct of the region of the Middle East and its constituent nations, including those discussed in more detail in the remainder of this volume. The discussion that we develop provides 


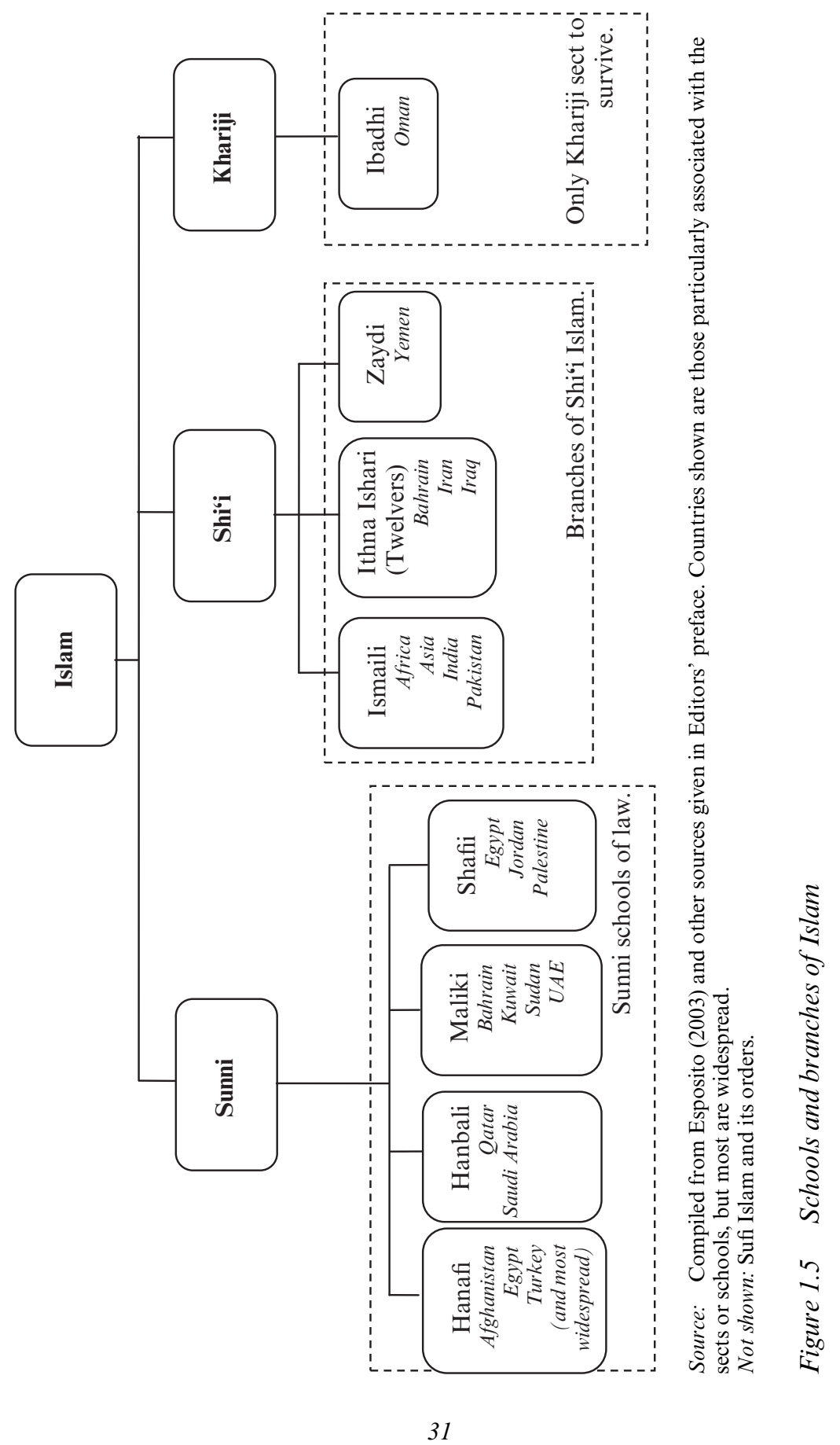


insights into how the Middle East as a concept and its constituent nation states came into being, how boundaries were set and reformed, and the colonial influence on that reconfiguration (Davidson 2008, 2009; Halliday 2000; Owen 1991). It is suggested that the colonial legacy still has ramifications for Middle East identity, but as subsequent chapters will demonstrate, the colonial past and colonial principles are being consigned to history in a renewal of cultural identity, bound to the nation or to Arab, Maghreb, Iranian and other identities (Ali 2005).

In order to contextualize the subject of leadership it is helpful to look at recent global developments pertinent to understanding sociocultural and geopolitical changes and to include themes such as democratization, gender, ethnicity and political economy. The justification for these themes is that, in their interrelation, they will reveal the complex multilayered factors that shape nationalisms, nation state building, organization systems and managerial policies, as well as gender and ethnic relations. Before these are examined, however, it is necessary to define the concepts and territories of the Middle East.

What we mean by 'Middle East' and its constituent nations is a controversial subject. The region provides rich contrasts in political, cultural, social and economic spheres. The three great monotheistic religions, Judaism, Christianity and Islam, were established through prophets and followers in these lands. The golden age of Islam (Ramadan 2009) witnessed the spread of Islam to Europe to the West and Asia to the East. The rich heritage of literature, thought, poetry and story telling - for example, as known in the West as the 'Arabian Nights', or the works of Omar Khayyam or Ibn Khaldun - composed in Arabia and communicated to Europe, informs us of great empires and a great respect for scientific reason, philosophy and the acquisition of knowledge (Ramadan 2009).

More recently, in the nineteenth and twentieth centuries, the Middle East was subject to colonial competition, resulting in moves towards modernization and economic development (Ali 2005). The modernization process has however been uneven and sporadic (Halliday 2010; Long et al. 2011; Milton-Edwards 2006).

The region is vast, with a number of borders and boundaries disputed and interpreted differently across cultures. Depending on which definition of the Middle East is used, the area stretches from Mauritania in the West to Iran in the East, and can include the East coast of sub-Saharan Africa and Turkey, Afghanistan and the Persian Gulf. Within this geographic territory there are vast deserts, ultra-modern cities such as Dubai, snow-capped mountains and vital natural resources, as will be discussed later in this chapter. The countries of this region differ in their histori- 
cal evolution, social composition and governance regime. Many of the countries can be considered Arab - on a definition based on language rather than geography - but not Afghanistan, Iran, Israel or Turkey, and several including Afghanistan, Iran and Iraq are ethnically diverse. All except Israel are predominantly Muslim, and of those all except Iran and Bahrain (Shi'i) and Oman (Ibadhi) are predominantly Sunni: 'however, the "Arab world" is not congruent as a concept with the 'Muslim world' as consideration of the status of, for example, Israel, Iran, Turkey, Pakistan and Afghanistan, or indeed Europe, will show' (Hurd 2006). However, the Arab League of 22 Middle East and North African nations remains a significant political and cultural organization.

That the region is inhabited by many religious groupings, despite the dominance of Islam, is linked to migration as well as to a resurgence in religiosity in general. Migration has created a diverse cultural mix of ethnic identities and religious affiliations, and many non-Muslims, for example Christian and Hindu expatriates, have played a large part in the development of the region. This is summarized in Table 1.2.

What, then, does define the Middle East? There are common historical reference points such as the death of the Prophet in $632 \mathrm{CE}$, or the fall of the Ummayad empire in $750 \mathrm{CE}$ : events common to the Islamic world as a whole, rather than to distinct regions. It is argued, however, that the Arabic language is in some sense an essence of Arab identity even beyond such shared historical legacy.

For the purposes of this book, we will define the Middle East as comprising the 16 states identified in Figure 1.6. Also shown but not identified are the nations of the 'Broader Middle East and North Africa' (BMENA) defined by the G8 and consisting of Afghanistan, Algeria, Bahrain, Egypt, Iran, Iraq, Jordan, Kuwait, Lebanon, Libya, Mauritania, Morocco, Oman, Pakistan, Qatar, Saudi Arabia, Sudan, Syria, Tunisia, Turkey, UAE, West Bank/Gaza and Yemen (G8-BMENA 2007).

The US has gone further in proposing policy based on a definition of a 'Greater Middle East', 'a large swath of Arab and non-Arab Muslim countries, stretching from Morocco in the west to as far east as Pakistan in southeast Asia' (Sharp 2005).

As Özbilgin states (Chapter 11), positioning Turkey with the Middle East is contentious. Although part of Turkey is geographically in Europe and the country is a candidate for EU accession, its relationship to Europe is debatable, although the concept of Europe is as amorphous and political (Hurd 2006; Yukleyen 2009) as is that of the Middle East. Further, Egypt is an African state with a strong Islamic heritage; however, so are others such as Sudan. Ultimately, we have chosen to adopt a 'traditional' definition of the Middle East consistent with that given in Esposito (2005, 


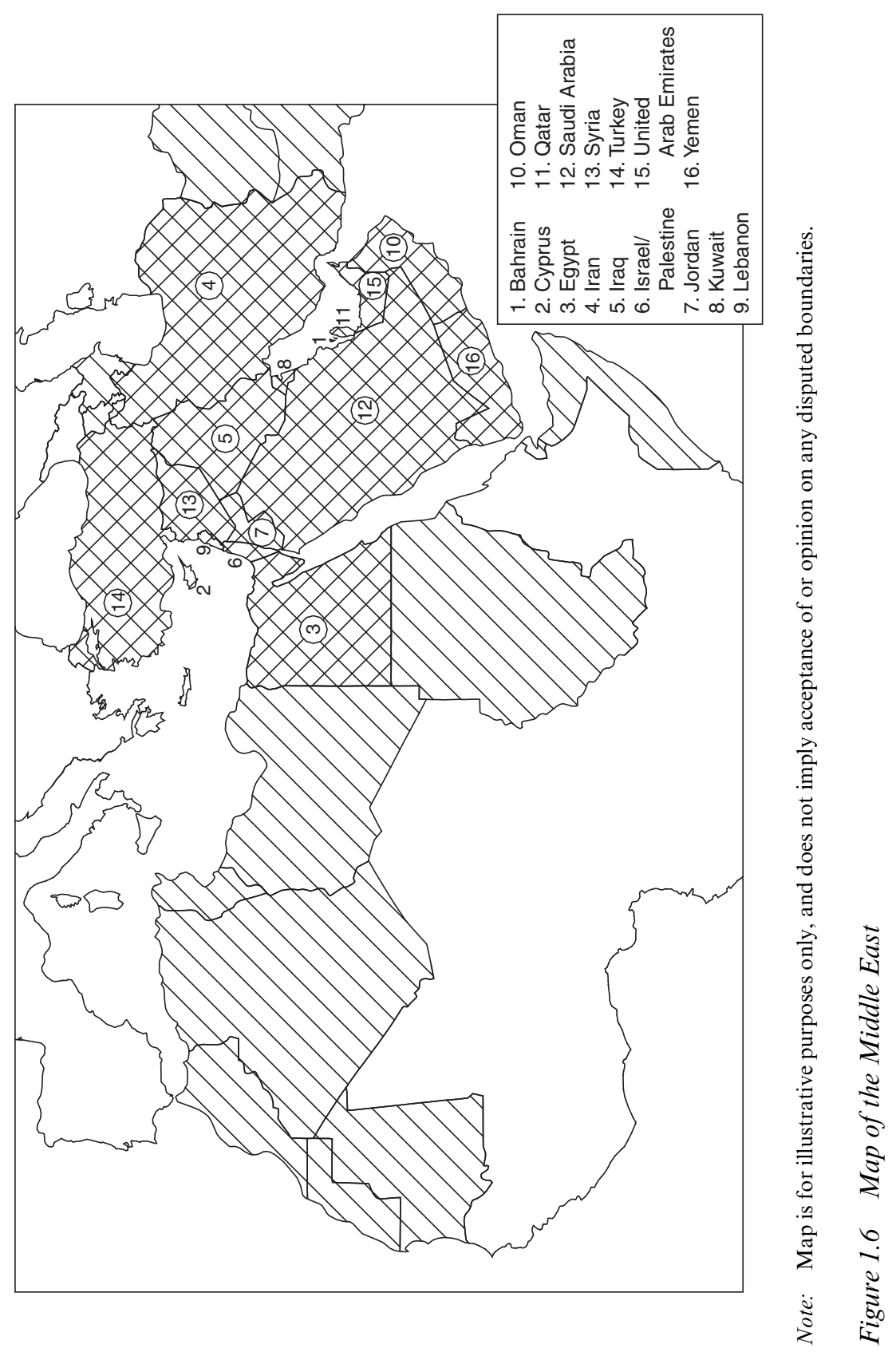


p. 200), while accepting that this is an arbitrary delineation. Within this definition, this book does not cover all countries but aims to provide a representative sample, including resource rich and resource poor, democratic and authoritarian states, along with generic chapters providing a detailed critique of specific issues across a broader range of countries.

\section{COLONIAL DISENGAGEMENT AND THE MIDDLE EAST}

The discussion in the section above brings to the fore the significance of how the Middle East as a geographic label has been constructed. The term is relatively new: this is important since the name creator was outside the geographical space which has become identified as Middle East: 'the Orient was almost a European invention' stated Palestinian academic Edward Said in Orientalism, his classic critique of the dominant Western concepts of the Middle East (Said 1978, p. 1). He went on to elucidate in poetic prose a dualism of night and day in which the Orient stood as the moon, the black, the negative, the backward, while the Occident represented the sun, the white, the positive, the enlightened and the progressive. Despite a homage to cultural knowledges, the West's construction of a Middle East positioned it as 'less than': less educated, less democratic and less developed - the 'other' against which are positioned dominant, developed Western nations:

The Orient is not only adjacent to Europe; it is also the place of Europe's greatest and richest and oldest colonies, the source of its civilizations and languages, its cultural contestant, and one of its deepest and most recurring images of the Other. (Said 1978, p. 1)

Western societies began to constitute themselves in a series of oppositions, for example: centre/periphery; developed/underdeveloped; scientific/ superstitious, and so on. This social construction led to a Western selfimage as a superior civilization. Once a link between superior West and inferior non-West was formed, colonialism became a culture and identity project that was acceptable to assist the process of 'improving, helping and civilizing' those states and peoples that were 'lagging behind' (Escobar 1998). Scholarship on the Middle East has progressed since Said's text brought to the fore debates between East and West about what constitutes development and reaffirmed both postcolonial and postructuralist understandings of knowledge, world order and power relations across and within developed, developing and transitional states (Utting 2006). These 
themes re-emerge throughout this book for, as we shall see, Arab Gulf states in particular are re-imagining development advances through an Islamic lens and thus have fundamentally different perspectives on transformation and change compared to Western states (Asutay 2007; Sharabi 1990).

Halliday (2007) takes a more pragmatic view, arguing that what happens in these societies is not as distinct or apart as imagined, but evolves from the cultural transference of ideas, concepts and interactions, aided by information and communication technology growth in the last twenty years and the advent of globalization (see also Castells 2009).

This discussion has indicated the complexity of the way in which the Middle East is defined. Orientalists and post colonialists have presented convincing debates about ongoing influence and control. In fact, for many states, colonial rule in the twentieth century was short lived, as will be discussed in the chapters that follow. It is beyond the scope of this text to examine this history in detail, but we feel it is necessary to touch on the most pertinent period, that between the First and Second World Wars.

It was at the end of World War I, associated with the break up of the Ottoman Empire, that governance regimes were comprehensively restructured. By 1922 the 'new' Middle East was emerging. New states were mandated to Britain and France under League of Nations auspices, states such as Jordan, Syria, Lebanon and Iraq, the boundaries of which paid little or no regard to the rich and diverse cultural and ethnic identities within them. During the inter-war period, colonial powers attempted to extend their control over the region, notably to Egypt and the Gulf: Milton Edwards (2005) coined the phrase 'merchants and missionaries', who impacted trade routes and development agendas across the region, communicating and infusing European ideals, values and practices.

After World War II the colonial powers faced greater resistance. There is no uniform picture that reflects and explains disengagement from British and French rule. However, the involvement of the newly established powers, the US and USSR, following the discovery of oil, altered international relations irrevocably. Perhaps only by 1956 and the Suez Crisis was the situation finally clear to the former powers. The new, developing links between the Middle East and the rest of the world forged new patterns of conflict and cooperation. This is summarized in Table 1.3.

Within these regions the issue of naming and labelling is one of identity, setting boundaries and social and political space between the peoples of the region and the world where the state seeks to create and establish identities which compete with other group identities focused on tribe, family, gender, ethnicity and religious affiliation. Platteau (2010) asks what exactly is Islamic influence, and is it Arab or Muslim identity that matters? Given 
Table 1.3 Twentieth century state formation in the Middle East

\begin{tabular}{|c|c|c|}
\hline Year & Event & Notes \\
\hline 1916 & Sykes-Picot Agreement & $\begin{array}{l}\text { Britain and France secretly plan to divide up Arab } \\
\text { Middle East. }\end{array}$ \\
\hline 1917 & Balfour Declaration & $\begin{array}{l}\text { British pledge to support Jewish settlement in } \\
\text { Palestine. }\end{array}$ \\
\hline 1918 & $\begin{array}{l}\text { Ottomans leave } \mathrm{N} \text {. } \\
\text { Yemen }\end{array}$ & Imamate established. \\
\hline 1920 & Treaty of Sèvres & $\begin{array}{l}\text { Division of the Ottoman Empire. Establishment of } \\
\text { British and French mandates. }\end{array}$ \\
\hline 1921 & Transjordan created & \\
\hline 1921 & Military coup in Iran & Reza Shah Pavlavi supplants Qajar regime. \\
\hline 1941 & British seize Lebanon & \\
\hline 1943 & Lebanon independence & Granted by 'Free French' authorities. \\
\hline 1943-6 & Syria independence & $\begin{array}{l}\text { Formal independence from Free French in } 1943 \text {, } \\
\text { withdrawal complete in } 1946 .\end{array}$ \\
\hline 1946 & $\begin{array}{l}\text { Transjordan } \\
\text { independence }\end{array}$ & Hashemite Kingdom of Jordan established. \\
\hline 1947 & Partition of Palestine & $\begin{array}{l}\text { UN partition into Jewish state, Arab state and } \\
\text { International area of Jerusalem. }\end{array}$ \\
\hline 1948 & Israel independence & First Arab-Israeli war. \\
\hline 1951 & Libya independence & $\begin{array}{l}\text { British and French petitions of 'trusteeship' } \\
\text { rejected by UN. }\end{array}$ \\
\hline 1952 & Military coup in Egypt & Nasser deposes King Farouk. \\
\hline 1953 & Egypt independence & \\
\hline 1953 & Coup in Iran & Backed by Britain and US and organized by CIA. \\
\hline 1956 & Suez Canal nationalized & $\begin{array}{l}\text { Suez War results, ended by intervention of US and } \\
\text { USSR. }\end{array}$ \\
\hline 1956 & Tunisia & \\
\hline 1957 & British leave Jordan & British-Jordanian treaty terminated by Jordan. \\
\hline 1958 & Military coup in Iraq & $\begin{array}{l}\text { Monarchy overthrown and independence } \\
\text { established. }\end{array}$ \\
\hline 1961 & Kuwait independence & \\
\hline 1962 & $\begin{array}{l}\text { Military coup in N. } \\
\text { Yemen. }\end{array}$ & Formation of Yemen Arab Republic. \\
\hline 1962 & Algeria independence & \\
\hline 1967 & S. Yemen independence & $\begin{array}{l}\text { Formation of People's Democratic Republic of } \\
\text { Yemen. }\end{array}$ \\
\hline 1968 & $\begin{array}{l}\text { British declaration of } \\
\text { intent }\end{array}$ & $\begin{array}{l}\text { Britain declares intention to withdraw from all } \\
\text { bases East of Suez within three years. }\end{array}$ \\
\hline 1971 & $\begin{array}{l}\text { Bahrain, Qatar \& UAE } \\
\text { independence }\end{array}$ & \\
\hline 1979 & Iranian revolution & Shah deposed and Islamic Republic of Iran created. \\
\hline 1990 & Unification of Yemen & \\
\hline
\end{tabular}

Sources: Cleveland and Bunton 2009; Long et al. 2011; Milton-Edwards 2007. 
the legacy of geopolitical, religious and historical dimensions, we argue that ethnicity and religion combine to form subjective positions at their intersection, and so are both pertinent (Escobar 1998; Ovendale 1998).

\section{HUMAN AND SOCIAL DEVELOPMENT}

As discussed above, Western powers have sustained authoritarian regimes and permitted theocracy governance to remain unchallenged despite ongoing scrutiny by Amnesty International and Human Rights Watch (Halliday 2000; UNDP 2003; UNDP 2009a; Utting 2006). The social development of Middle East countries is varied and characterized by uneven development (Pearson 2007; Utting 2006), with very diverse economies: Table 1.4 indicates that the Gross Domestic Product (GDP) per capita varies enormously across the region, with the richest country, Qatar, having an average income 43 times that of the poorest, Yemen. Even discounting these outliers, income levels in the region vary substantially. The most important factor driving these disparities is the huge variation in natural resource wealth, oil in particular, as the region includes oil-rich economies poor in other resources, oil-poor economies and mixed economies (Moghadam 1993) and what Moghadam (1993) terms 'city', 'desert' and 'normal' states. Natural resources are discussed later in this chapter. Another vital factor explaining uneven development is that the Arab region has suffered almost three times as much as any other region in the world in terms of years of conflict, over an 18-year period from 1990 to 2008 (UNDP 2010).

Demographic and social conditions also vary considerably across the Middle East. As Table 1.2 indicates, these countries differ widely in population, with three having populations greater than 60 million, six above 20 million and seven lower than 5 million.

\section{Millennium Development Goals}

Instability in governance regimes and the progress of democratization in most of the Middle East's resource-rich states has, to some extent, undermined development (Platteau 2010) as expressed in the Millennium Development Goals (MDGs) - what has been described as 'the world's biggest promise' (Hulme 2009). It is worth quoting from Ban Ki-Moon, UN secretary general, on the nature of the MDGs:

The Millennium Development Goals set timebound targets, by which progress in reducing income poverty, hunger, disease, lack of adequate shelter and 


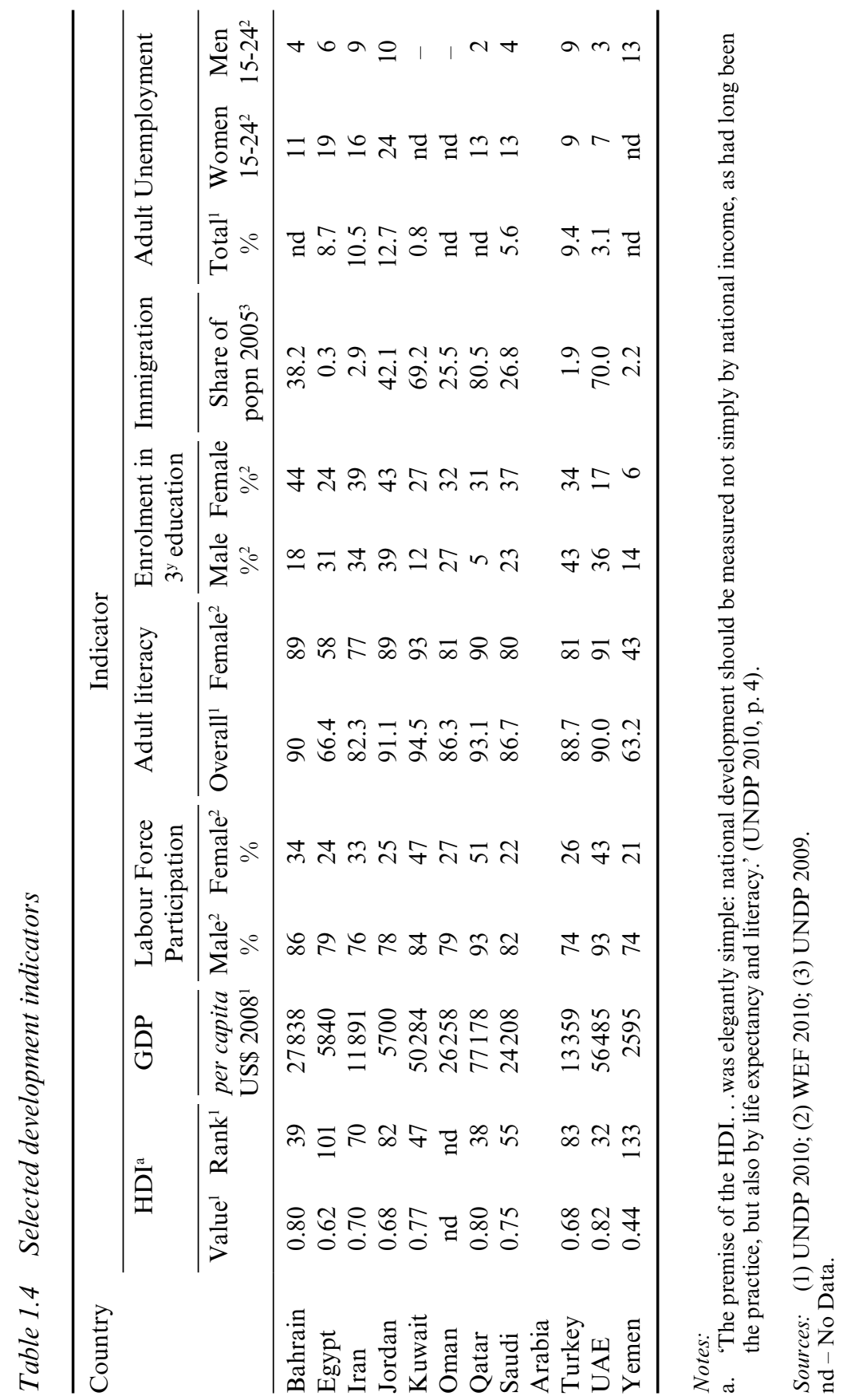


exclusion - while promoting gender equality, health, education and environmental sustainability - can be measured. They also embody basic human rights - the rights of each person on the planet to health, education, shelter and security. The Goals are ambitious but feasible and, together with the comprehensive United Nations development agenda, set the course for the world's efforts to alleviate extreme poverty by 2015 . (UN n.d.)

The Arab Human Development Report 2009 (UNDP 2009b) presents a useful critical overview of progress against MDGs. While progress against some measures has flourished beyond expectations, no progress has been made against other indicators. We will briefly discuss some of the indicators most relevant to this volume here.

The first of the goals is to eradicate extreme poverty and hunger. These issues are related, and hunger is also related to water availability for agriculture, which further impacts the target of improved access to safe drinking water, part of Goal 7 (ensure environmental sustainability). The challenges of economic stability and water availability are discussed later in this introduction, but it is significant that although the total numbers of undernourished in the Arab world are low, they rose between the study periods of 1990-1992 and 2002-2004 - one of the only two world regions where this was the case (UNDP 2009b).

Another example of the interconnectedness of MDGs is the relation of education (Goal 2) to a number of factors including maternal health (Goal 5). According to the Arab Human Development Report (AHDR): 'WHO statistics indicate that the most important factors accounting for disparity in health levels within Arab countries are income level, place of residence (urban or rural), and mother's educational level' (p. 151). Significant progress has been made in the area of education and particularly in women's education. As can be seen from Table 1.3, women's enrolment in tertiary education outstrips that of men in the majority of the nations considered. However, the gender inequality index shows that only 32 per cent of women in the region over 25 have completed secondary education, compared to 45 per cent for men (UNDP 2010). University enrolment shows the reverse, with 132 women enrolled for every 100 men (UNDP 2010).

More significant in terms of the MDGs is the illiteracy rate, a component of the UNDP's Human Poverty Index (HPI), referring to exclusion from reading and communication. Human poverty affects children's attendance and continuation in schooling: for example, in Egypt the attendance of poor children is 7 per cent lower than that of more affluent children in elementary school, 12 per cent lower at intermediate level and 24 per cent lower at secondary level (UNDP 2009b). The only nation covered in this volume with an HPI considered high is Yemen (36.6 per cent where the 
threshold is 30 per cent). Significantly, this is a nation where insecurity from lack of access to safe water and child nutrition is also significant.

Comparison with poverty reduction in other developing counties shows that Arab nations 'could do better': for example, the United Arab Emirates with a Human Development Index (HDI) rank of 31 has performed three times worse than Hungary with an HDI rank of 38 . This is true generally for Arab countries but not for Lebanon, Syria and Jordan - the education sector of which is discussed in Chapter 8. The significance of education indicators for women in particular will be discussed further in Chapter 13, but in general efforts to tackle poverty with respect to income, access to health services, and empowerment indicators such as access to resources and political decision making have been poor compared to other regions. There has also been criticism of revisions in reporting criteria in the 2010 Human Development Report. The UNDP changed the basis of inequality and poverty measures in this report, and commentators argue that this has blurred reporting of actual progress against development indicators, especially concerning gender indicators, and limits the ability to compare data series over time. Further, statistics on unemployment are questioned - many Arab states have high unemployment: Egypt and Turkey do not hide it, whereas other states, including the Gulf states, may do so, hiding the development challenges of high unemployment among women and young (15 to 24 -year-old) males.

The biggest obstacle to consistent development without overlooking poverty may be bureaucratic and monolithic state institutions (Platteau 2010), lack of democracy, and issues as discussed in the section below on strategic resources regarding rentier economies, migrant labour and the so called 'resource curse' (Bebbington 2008; Utting 2006; Wiefen 2008).

\section{Migration}

Migration and the international mobility of labour have made the states of the Persian Gulf unique in the world (Fragues 2006; World Bank 2008). The GCC states have by far the largest number of world migrants among them -18 per cent of the world total, comprising 38.6 per cent of their combined populations (UNDP 2009a). Nowhere other than in the GCC countries are local indigenous populations a minority of inhabitants: nowhere else does the majority of the population consist of migrants, with temporary residency, no access to citizenship and limited membership in society: nor are labour markets anywhere else so highly dependent upon the international recruitment of the workforce. This has highlighted a number of leadership and organization development challenges and is elaborated on in the chapters on Oman, Saudi Arabia and the UAE. 
The differential employment of nationals and expatriates shapes employment relations and strategy management, including HRD planning and career management, as well as efforts to integrate women (Metcalfe and Rees 2010). The dynamic of different employment status and the associated difference in - or absence of - rights, benefits and opportunities creates tension and conflict and will provide leaders with HR challenges for years to come. Moreover, it is HR skills that are particularly in demand to rectify this situation.

The characteristics of the migrant population are diverse. Many are the 'working poor' who tend to have limited education qualifications, who often do not appear in official statistics, and who are employed in construction, service and domestic work. Originally, migration strategies were adopted by states as a strategy to build the Arab nation. Gulf States adopted nationalization - so-called 'Gulfization' (Saudization, Emiratization, Omanization, etc.) - policies along two lines: on one side, reducing the supply of migrant workers by reinforcing barriers at entry and providing disincentives to stay, and on the other, limiting the demand for migrant workers by expanding the list of jobs reserved for nationals and placing a tax on employers who hire non-nationals. Gulfization policies have had mixed results and labour markets' dependency on migrant workers is still at a peak.

Economic and social developments are currently impacting Gulfization planning and it is difficult to assess how these influences will impact in the long term. There is still a rising demand that local supply may not be able to match for high-skill workers, either for lack of an adequate skills base or because an insufficient population of highly skilled nationals will increasingly expose the Gulf to what has become a global competition for talent. This is attributed to the inadequacy of local vocational and university programmes in matching requirements in skills and numbers. In contrast to low-skilled workers, who will still be needed (although in smaller numbers) in the construction sector or in domestic services and whose potential supply can be considered unlimited, high-level professionals needed for ambitious programmes such as the development and leadership of world-class universities like KAUST in Saudi Arabia remain a scarce resource worldwide. Their recruitment may test the competitiveness of Gulf labour markets in attracting the best and the brightest. In addition, the rise of global advocacy for migrants' rights, and the adoption of Corporate Social Responsibility ethics by organizations, may influence migrants' choice of destination (Pearson 2007). A further concern is local resistance to increased migration, and social movements may play a role to curb decades-old patterns of migration to the Gulf. Increasing competition between nationals and migrants, or mounting protests by migrant 
workers claiming their rights, may foster anti-immigration reactions and eventually affect stability.

\section{'ARABIA FELIX': THE MIDDLE EAST AND NATURAL RESOURCES}

A current knowledge gap in cross-cultural management and leadership studies is the uneven distribution of natural resources and the current and future effect of this on power relations in the global political economy (Hulme 2009; Utting 2006). In this section we look at the implications for leadership in the Middle East of the existence and distribution of natural resources, at the continuing importance of the region as a transit route for resources from within and outside its borders, and as a physical and symbolic link between East and West (Said 1978).

In the modern era, any discussion of the resources of the region must inevitably concentrate on fossil fuels, and especially oil. It must be recognized however that the region has been important as the source or shipment route for valuable resources since antiquity; and from this time observers have recognized that these resources were not homogeneously distributed. The Romans, translating the term Eudaimon Arabia recorded by Ptolemy, recognized Arabia Felix or fortunate Arabia; the Arabia of the relatively fertile South roughly congruent with modern Yemen. This is the land of which Herodotus wrote, 'The whole country is scented with [the spices of Arabia], and exhales an odour marvellously sweet'. By contrast, they also identified Arabia Deserta and Arabia Petraea, the desert and rocky lands of the interior and North (Halliday 2000; Ovendale 1998).

It is tempting to look at modern Arabia and define an Arabia Felix in terms of the presence or absence of oil. However, as Maass has observed of nations with reserves of oil: 'Petrodollars can make them richer but not more honest, efficient or intelligent' (Maass 2009, p. 6) - part of the socalled 'resource curse' discourse (Ross 1999). As discussed in the chapters that follow, the leaderships of the countries under discussion are facing up to the challenges of the presence or absence of oil, to inevitable "peak oil', and to the environmental consequences of oil extraction and consumption, in their individual ways. This is commented on further in the conclusion to this volume.

Complicating the resource issue is the fact that the resource rich nations in the region, primarily the GCC states, tend to be short of the labour required for the proper functioning of their economies. Conversely, the labour-rich, resource-poor nations from which they source their workforce are highly reliant on the remittances sent back by workers in the 
resource-rich countries; but these have proved vulnerable to both global economic instability and the geopolitical shifts of the region, as will be seen in the chapter on Yemen (Bjorvatn and Selvik 2008; Losman 2010; Marcel 2006; UNDP 2009b). The current balance of resources and remittances can be understood with reference to Table 1.4, with the resourcepoor nations relevant to this volume Egypt, Jordan, Turkey and Yemen. Additionally, ongoing nationalization programmes in the countries studied are already placing emphasis on the employment of local, national citizens (Hutchings, Metcalfe and Cooper 2010; Metcalfe and Rees 2010). As the preceding discussion on migration revealed, it is doubtful whether labour market policy and education reform will suffice to reverse nationalization programmes in line with millennium development goals and the development plans of individual states.

The result of the situation described in this section is that, as the Arab Human Development Report 2009 points out, the flow of oil wealth within the region is less significant than it once was. The AHDR summarizes this according to three reasons:

First, population increases in non-oil countries offset much of these flows. Second, worker remittances from the oil states have been hit by the practice of 'job nationalization'; and third, non-oil countries are incurring higher energy costs through rising oil import bills and expensive fuel subsidies. (UNDP 2009b)

\section{Between East and West: The Middle East and World Trade}

The Middle East also remains, as mentioned above and as its name suggests, a vital link between East and West. Several authors in this volume refer to the influence of ancient trade routes, known collectively as the Incense Route, which date back at least to the first millennium BCE and possibly back to the late Bronze Age (Artzy 1994). The most obvious symbol of ongoing trade through the region is the Suez Canal, which has been a key indicator of changing control and leadership in the region, from its construction as a colonial project (completed in 1869) to nationalization and the Suez Crisis - or tripartite aggression - of 1956, emblematic of the end of the colonial era, and the blockade and closure of the canal between 1967 and 1975 as a result of the Arab-Israeli wars. The canal and associated trade routes continue to develop into the twenty-first century: the Sumed pipeline allows the trans-shipment of oil from the Red Sea to the Mediterranean, and The Suez Canal Container Terminal now allows the same process with dry goods (Rodenbeck 2010, p. 8). 
Elsewhere in the region, the routeing of the Baku-Tbilisi-Ceyhan pipeline, as discussed in the chapter on Iran and designed as a matter of policy to decrease the influence of Iran and increase that of Turkey, can be seen as indicative of growing neocolonial influence.

Another aspect of the Middle East as a trade conduit is the development of Islamic finance. There are opportunities for, and competition between, countries, in the development of the expanding Islamic banking sector (Wilson 1995). Islamic finance in the form of Shar'ia-compliant sukuks is discussed in Chapter 2, but Dubai faces competition from Bahrain and the Kingdom of Saudi Arabia in the development of a model of finance which may connect to Western financial institutions, but is Shar'ia compliant.

As they affect leadership across many of the states discussed in this volume, this introduction will look in more detail at some of the issues mentioned above. We will discuss water resources, oil and gas, labour resources and remittances, and response to climate change below.

\section{Water, Development and Economic Growth}

Water has always been a critical resource for the region. Sheikh Yamani, former Saudi oil minister and head of OPEC, is famously quoted as saying: 'All in all, I wish we had discovered water' (quoted in Ross 1999). This reflects the fact that in the region considered by the Arab Human Development Report (UNDP 2009b), congruent with the Wider Middle East discussed above, 5 per cent of the world's population live in a region that contains only 1 per cent of the world's water supply. There are also food supply and security issues discussed at length in the same report. The region's ratio of agriculturally usable land to total land surface is only 35 per cent, 'the lowest in the world' (UNDP 2009b, p. 138). Exacerbating this, it is predicted that global warming will cause the climate to become hotter and drier, and desertification is an observable issue, threatening a fifth of the total land area of Arab nations (UNDP 2009b). The population is still growing rapidly in the region and the economic instability of 2008 caused a rise in world food prices which forced a re-evaluation of food strategy. Saudi Arabia and the UAE are prominent in investing in land, particularly in Sudan. Fahad Balghunaim, Saudi Arabia's agriculture minister, told an industry event: 'In Saudi we have given a priority to water security and therefore are phasing out the production of waterintensive crops and as part [of] our security strategy we are encouraging the private sector to invest in agriculture abroad' (Sudan Commerce News 2010). However, there is an element of irony that the country in which Arab states are investing to secure their food supply is the one with the 
largest population of people living in hunger (more than eight million) in the Wider Middle East (UNDP 2009b).

There is, however, the potential to develop other resources. Again, as attributed to Sheikh Yamani: 'The Stone Age came to an end not for a lack of stones' (quoted in Greider 2000) and there are significant alternatives to 'doomsday scenarios' of the end of the oil economy, including the exploitation of relatively abundant solar energy and, to a lesser extent, wind power. This will be discussed briefly in the section below on climate change.

\section{Strategic Resources: Gas and Oil}

One factor of enormous significance to the countries of the Middle East and the world is the future of oil reserves. The distribution of these across the region is highly non-homogeneous, but the social and economic effects have influence across national boundaries. This has both global geopolitical effects and short-distance effects, as on migrant labour, discussed above.

The oil-rich states of the Middle East are repeatedly referred to in the chapters that follow as 'rentier states'. This term originates in the concept of the landowner who lives entirely off the income from property that is rented out. In the context of this volume, it refers to the 'renting out' of natural resources, principally oil, to external bodies (Losman 2010). National income is then overwhelmingly derived from these revenues, which brings issues of its own. Losman (ibid.) argues that rentier states can be unstable. Rather than raising taxation income, the state is responsible for the distribution of rental incomes, leading to discontent among those unhappy with their share; and the legitimacy of rentier governments is based on culture, ideology and religion, which can become areas of conflict. However, elections 'are not the only source of legitimacy' (ibid. p. 430) and Common, discussing Oman in this volume, argues that an authoritarian regime can be more stable (Chapter 6).

Such economies contribute to the concept of a 'resource curse' as introduced above. This proposes that the citizens of oil-rich states do not benefit from the oil revenues that remain in the hands of relatively small elites. This concept is much discussed and it is reasonable to say that there is no strong correlation between resource wealth and development: 'There was prosperity and a measure of freedom in just a few cases, usually in tiny countries with disproportionately large reserves' (Maass 2009, p. 6) and, as will be seen in the rest of this volume, the culture, wealth and development of each state should be critically analysed on a case-by-case basis.

Migrant workers are critical not only to the economies of such rentier 
Table 1.5 Remittances

\begin{tabular}{lcccccc}
\hline \multicolumn{7}{c}{ Remittances: } \\
\hline Country & $\begin{array}{c}\text { HDI } \\
\text { Rank }\end{array}$ & $\begin{array}{c}\text { Inflows } \\
\text { US\$ } \\
\text { millions }\end{array}$ & $\begin{array}{c}\text { Outflows } \\
\text { US\$ } \\
\text { millions }\end{array}$ & $\begin{array}{c}\text { Inflows } \\
\text { per capita } \\
\text { US\$ }\end{array}$ & $\begin{array}{c}\text { As \% of } \\
\text { GDP }\end{array}$ & $\begin{array}{c}\text { Ratio to } \\
\text { FDI }\end{array}$ \\
\hline Bahrain & 39 & & 1483 & & & \\
Egypt & 123 & 7656 & 180 & 101 & 6.0 & 0.7 \\
Iran & 88 & 1115 & nd & 16 & 0.5 & 1.5 \\
Jordan & 96 & 3434 & 479 & 580 & 22.7 & 1.9 \\
Kuwait & 31 & & 3824 & & & \\
Oman & 56 & 39 & 3670 & 15 & 0.1 & 0.0 \\
Qatar & 33 & nd & nd & nd & nd & nd \\
Saudi Arabia & 59 & 16068 & 16 & 0.2 & 0.1 \\
Turkey & 79 & 1209 & 106 & & & \\
UAE & 35 & nd & nd & nd & nd & nd \\
Yemen & 140 & 1283 & 120 & 57 & 6.1 & 1.4 \\
\hline
\end{tabular}

Sources: (1) UNDP 2009 pp. 159-62. nd - No Data.

states but also to those of their nations of origin. As highlighted previously, the nations of the GCC together attract 18 per cent of all world migrants, forming 38.6 per cent of their combined populations (UNDP 2009a). The importance of remittances to the economies of Egypt, Yemen and Jordan, in particular, is apparent from Table 1.5 and is discussed further in the relevant chapters of this volume.

The countries of origin and destination of the workers providing the remittances are not shown in Table 1.5. However, as pointed out in the 2009 Human Development Report, 'Most movement occurs within regions' (UNDP 2009a, Map 2.1, p. 24). In essence, migration and remittances are mechanisms for the transfer of wealth, in this case primarily oil wealth, across national borders in the region. This makes the recipient nations especially vulnerable to future economic challenges associated with 'peak oil', climate change and new technology introductions. These challenges, discussed below, can only be met by developments in leadership capability, nationally, in business and in education, which will enable each society to foster private sector growth and respond to profound, rapid change.

The situation is complicated by political instability and conflict in the region (Maass 2009). Figure 1.7 indicates the effect of regional events on global oil prices. It is apparent that events in the Middle East are critical to global economics. In fact, not shown on the diagram are the effects of 


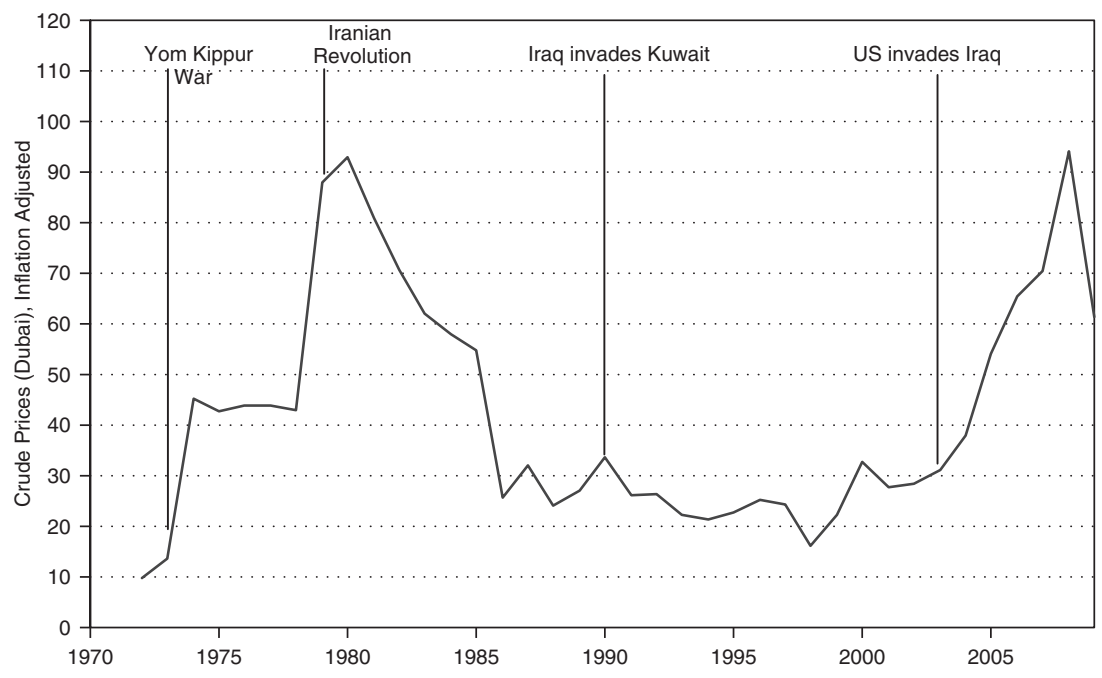

Source: BP Statistical Review of World Energy 2010.

\section{Figure 1.7 Oil price history}

interventions by OPEC to smooth out the effects of external events by regulating production. Without such efforts the fluctuations would certainly be even more dramatic.

However, the influence that can be exerted by such supply-side control will soon be diminished, as the ability of the oil fields to increase supply to meet growing global demand diminishes and then disappears. This phenomenon, known as 'peak oil', is inevitable, but the complex and interacting effects on demand both for oil and for alternative energy sources are unpredictable. Many authorities believe that global 'peak oil' is imminent, with Owen, Inderwildi and King (2010) suggesting that demand will outstrip supply at some point between 2010 and 2015 .

It is reasonable to assume that the importance of the Middle East in a world in which oil supply and demand are mismatched will only become more significant. As Aleklett observes:

Only in the Middle East and possibly the countries of the former Soviet Union is there a potential to significantly increase production rates to compensate for decreasing production rates in other countries. Saudi Arabia is a key country in this context, providing 95 million barrels per day $(11 \%$ of the current global production rate). Their proven reserves are 130 billion barrels and their reserve base is said to include an additional 130 billion barrels. Iraq also has considerable untapped oil reserves. (2007, p. 61) 
It is then reasonable to ask, what is the effect of such developments on leadership in the region? Iraq's justification for the 1990 invasion of Kuwait was alleged Kuwaiti 'theft' of Iraqi oil by lateral drilling, and it is generally believed that at least part of the US motivation for 'regime change' in Iraq has been control of oil supply: 'The question is not whether the war is about oil but how it is about oil' (Maass 1999 p. 159).

The effects of such struggles for the resources of the region can be less direct but just as devastating. Yemen paid a high price in the Gulf War of 1990, when the government supported Iraq and consequently found expatriate labour displaced from Iraq and Kuwait and forced out of Saudi Arabia by the tens of thousands (Colton 2010). The effects of these events have persisted to the present day, as discussed in the chapter on Yemen.

The distribution of oil in the region under consideration is shown in Table 1.6.

It should be noted that the reserves to production $(\mathrm{R} / \mathrm{P})$ ratio provides only a crude indication of future oil (and gas) supply. It does not take into account growth or other variation in demand, especially from developing economies, nor their interaction with price or the economics of recovery of the reserves. External factors such as economic sanctions or conflict may artificially depress production and exaggerate the apparent longevity of reserves (Bjorvatin Selvik 2008).

Reserves of gas, in particular, may be under-exploited, despite the West's 'dash for gas' of the 1990s. This arises from the relative difficulty of transporting gas from remote production areas to markets. Multinational corporations are investing hugely in liquefaction plant and refrigerated shipping for liquefied natural gas (LNG) and in gas to liquids (GTL) technologies. For example, Shell is involved in the Qatargas IV LNG facility, the final stages of which are commissioning at the time of writing, with a total investment from all sources of \$8 billion (Reuters): also in Qatar, Shell is investing in the Pearl GTL plant, the total project cost of which is $\$ 19$ billion (LNG World News). These investments will inevitably have implications for leadership development in the region, beyond that associated with traditional oil exploitation, and this is an area worthy of further study.

As the IEA states: 'oil production is projected to concentrate in an evershrinking group of countries with large reserves - notably Middle East OPEC member countries and Russia' (IEA 2007). Such a concentration will inevitably have an impact on political leadership in the region. The nature of such impacts will be unpredictable (Halliday 2010) .

The foregoing discussion suggests that strategic approaches at national level, particularly in the Arabian Gulf, have been slow to consider broader environmental and development impact. Christopher Davidson's work on 
Table 1.6 Proven fossil fuel reserves

\begin{tabular}{|c|c|c|c|}
\hline \multicolumn{4}{|c|}{ OIL } \\
\hline \multirow[t]{2}{*}{ Country } & Proven Reserves & Production & $\begin{array}{c}\text { Reserves to } \\
\text { Production }(\mathrm{R} / \mathrm{P}) \\
\text { Ratio }\end{array}$ \\
\hline & gigabarrels & 1000 barrels/day & Years \\
\hline Bahrain & - & - & - \\
\hline Egypt & 4.4 & 742 & 16.2 \\
\hline Iran & 137.6 & 4216 & 89.4 \\
\hline Iraq & 115.0 & 2482 & 126.9 \\
\hline Kuwait & 101.5 & 2481 & 112.1 \\
\hline Oman & 5.6 & 810 & 18.9 \\
\hline Qatar & 26.8 & 1345 & 54.6 \\
\hline Saudi Arabia & 264.6 & 9713 & 74.6 \\
\hline Syria & 2.5 & 376 & 18.2 \\
\hline UAE & 97.8 & 2599 & 103.1 \\
\hline Yemen & 2.7 & 298 & 24.8 \\
\hline Other ME & 0.1 & 37 & 7.4 \\
\hline \multicolumn{4}{|c|}{ GAS } \\
\hline \multirow[t]{2}{*}{ Country } & Proven Reserves & Production & R/P Ratio \\
\hline & $\begin{array}{c}\text { trillion cubic } \\
\text { metres }\end{array}$ & $\begin{array}{l}\text { billion cubic } \\
\text { metres/yr }\end{array}$ & Years \\
\hline Bahrain & 0.09 & 12.8 & 7.0 \\
\hline Egypt & 2.19 & 62.70 & 34.9 \\
\hline Iran & 29.61 & 131.20 & 225.7 \\
\hline Iraq & 3.17 & - & - \\
\hline Kuwait & 1.78 & 12.50 & 142.4 \\
\hline Oman & 0.98 & 24.80 & 39.5 \\
\hline Qatar & 25.37 & 89.30 & 284.1 \\
\hline Saudi Arabia & 7.92 & 77.50 & 102.2 \\
\hline Syria & 0.28 & 5.80 & 48.3 \\
\hline UAE & 6.43 & 48.80 & 131.8 \\
\hline Yemen & 0.49 & - & - \\
\hline Other ME & 0.06 & 4.50 & 13.3 \\
\hline
\end{tabular}

Source: Compiled from BP Statistical Review of World Energy 2010.

the growth of the UAE, Abu Dhabi and Dubai in particular, illustrated 'disconnected' logistics in Ministry regimes, and the pursuit of 'flamboyant development' to attract foreign direct investment (FDI), tourism and other income without consideration of an integrated infrastructure to 
manage transport, water, housing and public services. The global financial crisis has exaggerated such deficiencies in 'joined up' environmental planning, but it has been carefully monitored in global media representations (see also Asutay 2007).

\section{Climate Change}

In 2004, the authors of this introduction were given a tour of Bahrain by a senior, Western-educated manager with the national gas producer, Banagas. On being shown the highest point of the low-lying island, he was asked whether there was much concern about the effects of global warming. His reply was, 'What is global warming?'

This response may have been characteristic of Middle East attitudes only a few years ago, but the nations have been making a rapid effort to catch up with a more rational and widely-accepted approach to the environmental consequences of uncontrolled burning of fossil fuels. The formation of the Arab Forum for Environment and Development (AFED) in 2006 was a significant forward step. Still, in the Climate Change Performance Index 2009 comparing the climate change performance of the 57 countries responsible for 90 per cent of energy related $\mathrm{CO}_{2}$ emissions, Saudi Arabia was ranked last.

Yet the nations of the Middle East are vulnerable to climate change. Sea level rise may impact the most densely populated regions of Egypt severely, but it will also have an effect on low-lying states such as UAE, Qatar, Bahrain and Kuwait (Tolba and Saab 2009). It is also predicted that the distribution of rainfall will be altered, projected to make the Middle East hotter and dryer than at present. As the 2009 AFED report found:

virtually no work is being carried out to make the Arab countries prepared for climate change challenges. Specifically, no concerted data gathering and research efforts could be traced regarding the impacts of climate change on health, infrastructure, biodiversity, tourism, water and food production. The economic impact seems to be totally ignored. Reliable records on climate patterns in the region barely exist. (Tolba and Saab 2009)

As Reiche (2010) has pointed out for the GCC states, there is potential for renewable energy development in the region, especially in terms of solar energy (see Table 1.7) (ibid. p. 2401). It has also been pointed out that the situation of Egypt is equally propitious for solar energy generation, but also has high potential for wind power generation which it has now begun to exploit with windfarms on the Gulf of Suez and World Bank support to connect these to the Nile valley (Rodenbeck 2010). 


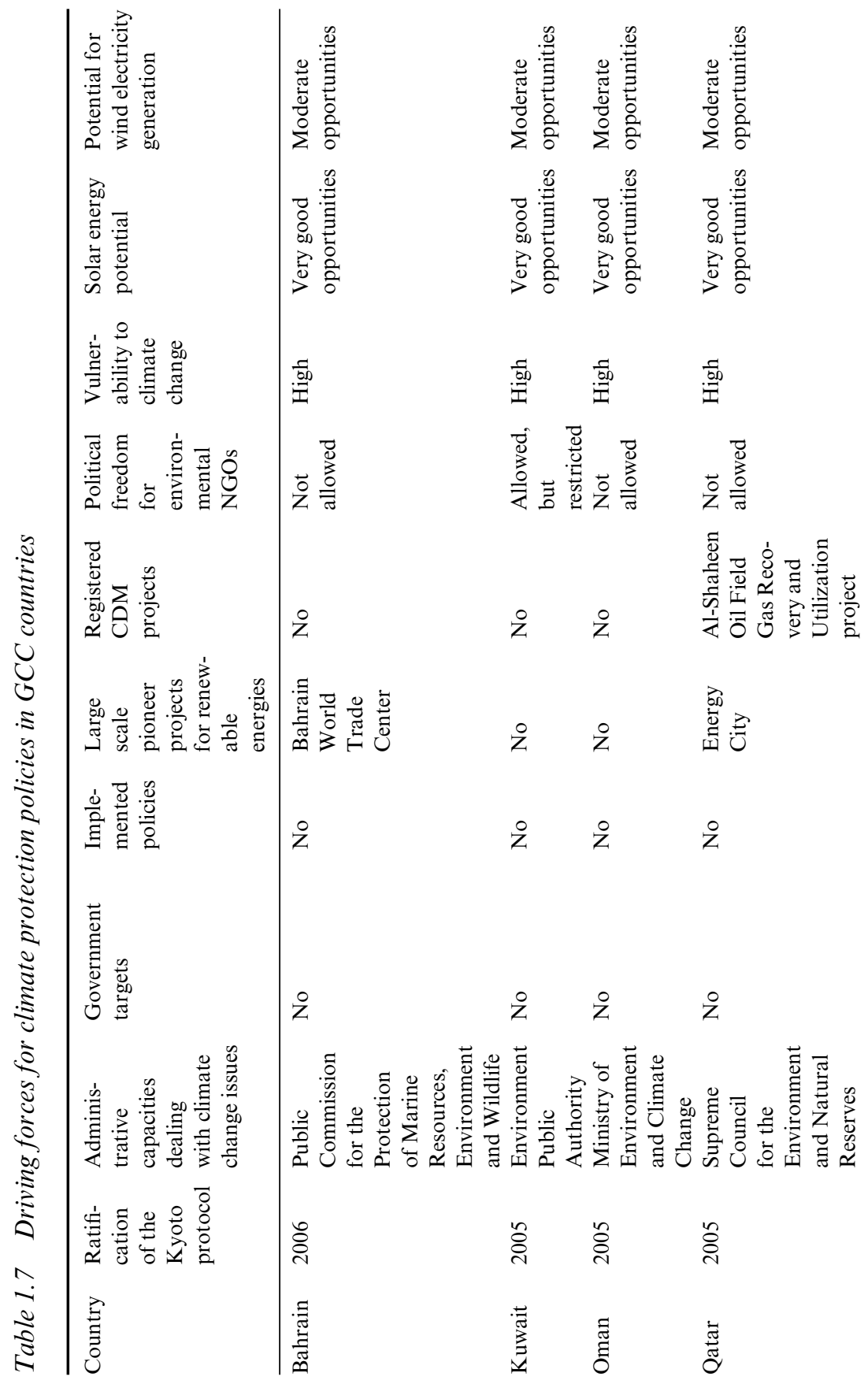




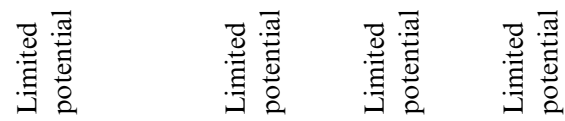

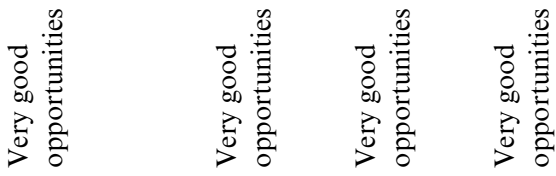

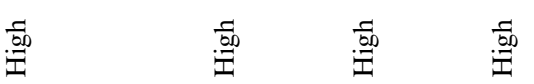

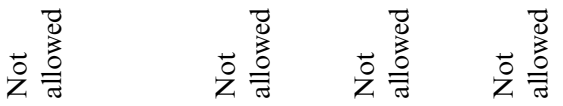

z

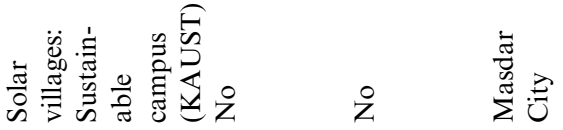

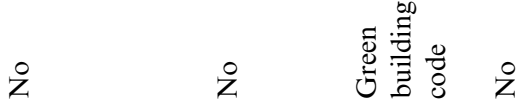

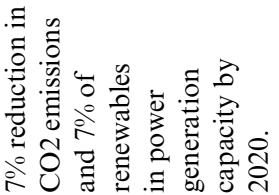

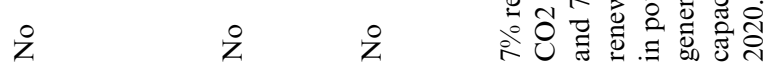

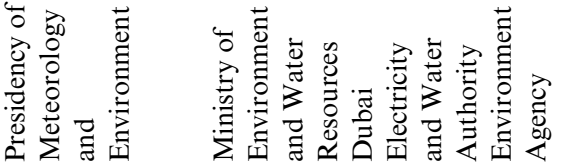

§ิ)

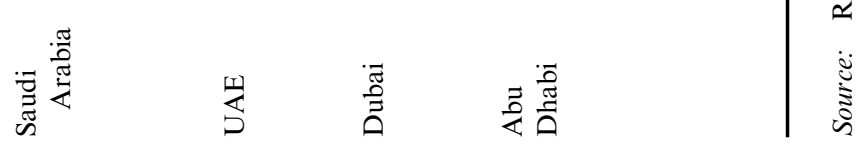




\section{SUMMARY}

This volume offers views of leadership from studies of individual Middle East states. As such, many of the dominant Western constructions are challenged, reconfigured or resisted. The collection reflects a critical interpretative account of leadership by drawing on knowledge territories as diverse as Middle East studies, feminism, geography, international relations and postcolonial development, as well as Western organization and leadership writings that examine diverse geographical regions.

This multidisciplinary approach arises inevitably from a field of study in which the intersection of a range of factors is critical: factors that include the resurgence of Islam, the intricacies of governance regimes, social development and the complex influence of climate change, all provide challenges for leaders in political and organizational spheres. We position leadership in the broader political economy, as not to do so would present only a partial, inadequate portrayal of leadership behaviour and identities as defined by the economic, religiopolitical and environmental dynamics.

Our aim is to advance new knowledge about leadership behaviour and practice, and arising from our review of the leadership scholarship of the West, we reaffirm that this is partial: restating or reconfiguring Western leadership theories cannot provide an adequate model for Middle East leadership. By integrating myriad subject domains and opening up communication and dialogue between East and West, Global South and Global North, a richer view of leaders is developed that allows us to rethink, freshly reimagine and represent the concept of leadership.

\section{REFERENCES}

Ahmed, A.S. (1992), Postmodernism and Islam, London and New York: Routledge. Ahmed, A.S. and H. Donnan (eds) (1994), Islam, Globalization and Postmodernity, London and New York: Routledge.

Aleklett, K. (2007), Peak Oil and the Evolving Strategies of Oil Importing and Exporting Countries: Facing the hard truth about an import decline for the OECD countries, Organisation for Economic Cooperation and Development/ITF discussion paper no. 2007-17, Uppsala, Sweden.

Ali, A.J. (2005), Islamic Perspectives on Management and Organizations, Cheltenham, UK and Northampton, MA, USA: Edward Elgar.

Alimo-Metclafe, B. (1998), Effective Leadership, London: Improvement and Development Agency.

Arab News (2006), 'Princess Adelah bint Abdullah talks of women's issues', accessed 22 December 2010 at http://archive.arabnews.com/?page=21\&section= $0 \&$ article $=90234 \& \mathrm{~d}=22 \& \mathrm{~m}=12 \& \mathrm{y}=2006$.

Artzy, M. (1994), 'Incense, camels and collared rim jars: desert trade routes and 
maritime outlets in the second millennium', Oxford Journal of Archaeology, 13, $121-47$.

Asutay, M. (2007), 'A political economy approach to Islamic economics: systematic understanding for an alternative economic system', Kyoto Bulletin of Islamic Area Studies, 1 (2), 3-18.

Asutay, M. and N. Zaman (2009), 'Divergence between aspirations and realities of Islamic economics: a political economy approach to bridging the divide', IIUM Journal of Economics and Management, 17 (1), 73-96.

Al-Attas, S.M.N. (1995), Prologomena to the Metaphysics of Islam: An Exposition of the Fundamental Elements of the Worldview of Islam, Kuala Lumpur: International Institute of Islamic Thought and Civilization.

Barnard, C. (1938), The Functions of the Executive, Cambridge, MA: HUP.

Bass, B.M. and B.J. Avolio (1990), Multifactor Leadership Questionnaire, Palo Alto, CA: Consulting Psychologists Press.

Bass, B.M. and B.J. Avolio (1994), Improving Organization Effectiveness Through Transformational Leadership, London: Sage.

Bebbington, A.J. (2008), 'Social capital and development studies II: can Bourdieu travel to policy', Progress in Development Studies, 7 (2), 155-62.

Beekun, J. and R.I. Badawi (1999), Leadership: An Islamic Perspective, Beltsville, MD: Amana Press.

Berkey, J.P. (2003), The formation of Islam: religion and society in the Near East, 600-1800, Cambridge: Cambridge University Press.

Bjorvatin, K. and K. Selvik (2008), 'Deconstructive competition: factionalism and rent seeking in Iran', World Development, 20, 1.

Bourdieu, P. and J.C. Passeron (1977), Reproduction in Education, Society and Culture, London and Beverly Hills, CA: Sage.

Bryman, A. (1992), Charisma and Leadership in Organizations, London: Sage.

Burns, J.M. (1978), Leadership, New York: Harper and Row.

Calas, M.B. and L.L. Smirchich (1991), 'Voicing seduction to silence leadership', in K. Grint (ed.) (1997), Leadership: Classical, Contemporary and Critical Approaches, Oxford: Oxford University Press.

Campbell, R.A. (2008), 'Leadership succession in early Islam: exploring the nature and role of historical precedents', The Leadership Quarterly, 19, 426-38.

Castells, M. (2009), The Rise of the Network Society: The Information Age: Economy, Society, and Culture, vol I, 2nd edn, Chichester: John Wiley.

Chapra, U. (1993), Islam and Economic Development, Pakistan and Malaysia: Institute of Islamic Thought and Islam Research Institute.

Choudhury, M.A. (1993), 'A critical examination of the concept of Islamisation of knowledge in contemporary times', Muslim Education Quarterly, 10 (4), 3-34.

Ciulla, J.B. (1995), 'Leadership ethics: mapping the territory', Business Ethics Quarterly, 5 (11), 5-28.

Ciulla, J. B. (2005), 'Integrating leadership with ethics: is good leadership contrary to human nature?', in J.P. Doh and S.A. Stumpf (eds), Handbook on Responsible Leadership and Governance in Global Business, Cheltenham, UK and Northampton, MA, USA: Edward Elgar.

Cleveland, W.L. and M. Bunton (2009), A History of the Middle East, 4th edn., Boulder, CO: Westview.

Colton, N.A. (2010), 'Yemen: a collapsed economy', The Middle East Journal, 64 (3), 410-26

Collinson, D. and J. Hearn (2004), 'Men and masculinities', in M. Kimmel, 
J. Hearn and R.W. Connell, Handbook of Studies on Men and Masculinities, Thousand Oaks, CA: Sage.

Crush, J. (1998), 'Imagining development,' in J. Crush (ed), The Power of Development, London: Routledge, pp. 1-24.

Davidson, C. M. (2008), Dubai: The Vulnerability of Success, New York: Columbia University Press.

Davidson, C.M. (2009), Abu Dhabi: Oil and Beyond, New York: Columbia University Press.

Deetz, S., S. Tracy and S. Simpson (2000), Leading Organizations through Transitions: Communication and Cultural Change, Thousand Oaks, CA: Sage.

Doh, J.P. and S.A. Strumph (2005), 'Toward a framework of responsible leadership', in J. Doh and S. Strumpf (eds), Handbook on Responsible Leadership and Governance in Global Business, Cheltenham, UK and Northampton, MA, USA: Edward Elgar, pp. 114-34.

Dunning, J.H. (2007), 'A new zeitgeist for international business activity and scholarship', European J. International Management, 1 (4), 278-301.

Escobar, A. (1998), 'Imagining a post development era', in Crush, J. (ed.), The Power of Development, London: Routledge.

Esposito, J.L. (2003), The Oxford Dictionary of Islam, paperback edn. (2004), New York: Oxford University Press.

Esposito, J.L. (2005), Islam: The Straight Path, 3rd edn, New York: Oxford University Press.

Fairclough, N. and E. Chiapello (2005), 'Understanding the new management ideology. A transdisciplinary contribution from critical discourse analysis and new sociology of capitalism', Discourse \& Society, 13 (2), 185-208.

Fairclough, N. (2007), 'The contribution of discourse analysis to research on social change', in N. Fairclough, P. Cortese and P. Ardizzone (eds), Discourse in Contemporary Social Change, New York: Peter Lang.

Fargues, P. (2006), 'International migration in the Arab region: trends and policies', United Nations Expert Group Meeting on International Migration and Development in the Arab Region, May 2006, Beirut accessed 17 January 2011 at www.un.org/esa/population/migration/turin/Symposium_Turin_files/ P09_Fargues.pdf.

Al-Faruqi, I.R. (1982), Tawhid: Its Implications for Thought And Life, Kuala Lumpur: IIIT.

Al-Faruqi, I.R. (2000), Meta-Religion: A Framework for Moral Theology, Washington, DC: Institute for Strategic Studies.

G8-BMENA (2007), accessed 9 December 2010 at www.g8-bmena-education.de/ en/101.php.

El Ghazali, A.H. (1994), Man is the Basis of the Islamic Strategy for Economic Development, Jeddah, Saudi Arabia: Islamic Research and Training Institute (IDB).

El Ghazili, Abdel H. (2002), 'Ihyaa Uloum Addin' 'The revival of religious sciences', in H.H. Ahmad (ed.), (1995), Al-Idarah al-Ammah Fi al-Islam: al-Osoul wa al-Tatbiq [Public Administration in Islam: Foundations and Practices], Riyadh: Al-Nawabi Publishing.

Greenleaf, R.K. (1977), Servant Leadership, Mahwah, NJ: Paulist Press.

Greider, W. (2000), 'Oil on political waters', The Nation, 271 (12), 5-6.

Grint, K. (ed) (1997), Leadership: Classical, Contemporary and Critical Approaches, Oxford: Oxford University Press. 
Grint, K. (2005), 'Problems, problems, problems: the social construction of leadership', Human Relations, 58 (11), 1467-94.

Grint, K. (2009), 'The sacred in leadership: separation, sacrifice and silence', Organization Studies, 31 (1), 89-107.

Halliday, F. (2010), The Middle East in International Relations: Power, Politics and Ideology, 2nd edn, Cambridge: Cambridge University Press.

Halliday, F. (2000), Nation and Religion in the Middle East, London: Saqi.

Hausmann, R., L.D. Tyson and S. Zahidi (2010), The Global Gender Gap Report 2010, Geneva, Switzerland: World Economic Forum.

Hearn, J.B.D. Metcalfe and R. Piekarri (2011), 'Gender, intersectionality and IHRM', in G.K. Stahl and I. Björkman (eds), Handbook of Research in International Human Resource Management, Cheltenham, UK and Northampton, MA, USA: Edward Elgar.

Hersey, P. and K.H. Blanchard (1988), Management of Organisation Behaviour, 5th edn, Englewood Cliffs, NJ: Prentice Hall.

Hofstede, G. (1980), Culture's Consequences:International Differences in Work Related Values, London: Sage Publishers.

Hofstede, G. (1983), 'The cultural relativity of organization practices and theories', Journal of International Business Studies, 14 (2), 75-89.

Hofstede, G. (2003), Culture's Consequences, Comparing Values, Behaviors, Institutions, and Organizations Across Nations, 2nd ed, London and Thousand Oaks, CA: Sage Publications.

House, R.J., M. Javidan, P.J. Hanges, P.W. Dorfman and V. Gupta, (eds) (2004), Culture, Leadership, and Organizations: The GLOBE Study of 62 Societies, London and Thousand Oaks, CA: Sage.

Hulme, D. (2009), 'Global poverty reduction and the millennium development goals: a short history of the world's biggest promise', Brooks World Poverty Institute working paper.

Hurd, E.S. (2006), 'Negotiating Europe: the politics of religion and the prospects for Turkish accession', Review of International Studies, 32, 401-18.

Hutchings, K., B. D. Metcalfe and B. Cooper (2010), 'Exploring middle eastern women's perceptions of barriers to, and facilitators of, international management opportunities', International Journal of Human Resource Management, 21(1), 61-83.

IEA (2007), Oil Supply Security, Paris: OECD/IEA.

Islam, G. (2009), 'Animating leadership: crisis and renewal of governance in 4 mythic narratives', Leadership Quarterly, 16 (5), 777-806.

Javidan, M., P.W. Dorffman and M. Sully de Luque and R.J. House (2006), 'In the eye of the beholder: cross cultural lessons in leadership from project GLOBE', Academy of Management Perspectives, 20 (1), 67-90.

Kabasakal, H. and A. Dastmalchian (2001), 'Introduction to the special issue on leadership and culture in the Middle East', Applied Psychology: An International Review, 50 (4) 479-88.

Lawrence, T.E. (1926), Seven Pillars of Wisdom, London: Private.

Lewis, B. (2002), What Went Wrong? Western Impact and Middle Eastern Response, London: Weidenfeld and Nicholson.

Lewis, B. and B.E. Churchill (2009), Islam: The Religion and the People, Upper Saddle River, NJ: Wharton School Publishing.

Long, D.E., B. Reich and M. Gasiorowski (eds) (2011), The Government and Politics of the Middle East and North Africa, Boulder, CO: Westview Press. 
Losman, D.L. (2010), 'The rentier state and national oil companies: an economic and political perspective', Middle East Journal, 64 (3), 426-45.

Maak, T. (2007), 'Responsible leadership, stakeholder engagement, and the emergence of social capital', Journal of Business Ethics, 74, 329-43.

Maass, P. (2009), Crude World: The Violent Twilight of Oil, London: Allen Lane.

Marcel, V. (2006), Oil Titans: National Oil Companies in the Middle East, London: Chatham House.

Meindl, J.R. (1995), 'The romance of leadership as follower-centric theory: a social construction approach', Leadership Quarterly, 6 (4), 329-41.

Metcalfe, B.D. (2008), 'Women, management and globalization in the Middle East', Journal of Business Ethics, 81 (1), 85-100.

Metcalfe, B.D. (2010), 'Reflections on difference: women, Islamic feminism and development in the Middle East', in J. Sayed and M. F. Özbilgin (eds), Managing Gender Diversity in Asia, Cheltenham, UK and Northampton, MA, USA: Edward Elgar.

Metcalfe, B. D. and C. Rees (2010), 'Gender, globalization and organization: exploring power, relations and intersections' Equality, Diversity and Inclusion: An International Journal, 29 (1), 5-22.

Miller A. (1947) All My Sons, London: Penguin.

Milton-Edwards, B. (2006), Contemporary Politics in the Middle East, 2nd edn, Cambridge: Polity Press.

Moghadam, V.M. (2003), 'Towards gender equality in the Arab/Middle East region: Islam, culture, and feminist activism', Human Development Report Office occasional paper, background paper for HDR 2004, United Nations Development Programme.

Morgan, M.H. (2007), Lost History: The Enduring Legacy of Muslim Scientists, Thinkers and Artists, Washington, DC: National Geographic Association.

Noor, I. (1999), Prophet Muhammad's Leadership: The Paragon of Excellence and Altruistic Management, Kuala Lumpar, Utusan Publications.

Norris, P. and R. Ingleheart (2002), 'Islamic culture and democracy: testing the "clash of civilizations" thesis', Comparative Sociology, 1 (3-4), 235-63.

Al-Omar, F.A. (1999), Akhlaqu-al-Amal [Work Ethics], Jeddah, Saudi Arabia: Islamic Research and Training Institute.

Al-Omari, J. (2005), The Arab Way: How to Work More Effectively with Arab Cultures, Oxford: Howtobooks.

Onley, J. and S. Khalaf (2006), 'Shaikhly authority in the pre-oil Gulf: an historical-anthropological study', History and Anthropology, 17 (3) (September), 189-208.

Ovendale, R. (1998), The Longman Companion to the Middle East Since 1914, London: Longman.

Owen, R. (1991), State, Power and Politics in the Making of the Modern Middle East, Oxford: Polity Press.

Owen, N.A., O.R. Inderwildi and D.A. King (2010), 'The status of conventional world oil reserves - hype or cause for concern?', Energy Policy, 38, 4743-9.

Pearson, R. (2007), 'Beyond women workers: gendering corporate social responsibility', Third World Quarterly, 28 (4), 731-49.

Pew Research Center (2009), Mapping the Global Muslim Population, Washington, D.C.: Pew Research Center.

Platteau, J.P. (2008), 'Religion, politics, and development: lessons from the lands of Islam', Journal of Economic Behaviour, 68 (2), 329-51. 
Platteau, J.-P. (2010) 'Political instrumentalization of Islam and the risk of obscurantist deadlock' World Development, 39 (2), 243-60.

Qur'an (2004), translated by M.A.S. Abdel, Haleem, New York: Oxford University Press.

Ramadan, T. (2004), Western Muslims and the Future of Islam, New York: Oxford University Press.

Ramadan, T. (2009), Radical Reform: Islamic Ethics and Liberation, New York: Oxford University Press.

Reiche, D. (forthcoming), 'Driving forces for climate protection policies in GCC countries', Energy Policy.

Rodenbeck, M. (2010), 'A special report on Egypt', The Economist, 15 July.

Rosnor, J. (1990), 'Ways women lead', Harvard Business Review, Nov/Dec, $119-25$.

Ross, M. (1999), 'The political economy of the resource curse', World Politics, 51 (2), 297-322.

Roy, O. (2002), Globalised Islam: The Search for a new Ummah, London: C. Hurst $\&$ Co.

Said, E. (1978), Orientalism: Western Conceptions of the Orient, revised edn (1995), London: Penguin.

Sarayrah, Y.K. (2004), 'Servant leadership in the Bedouin-Arab culture', Global Vitue Ethics Review, 5 (3), 58-79.

Sashkin, M. (1988) 'The Visionary Leader', in J.A. Conger and R.N. Kanungo (eds), Charismatic Leadership: The Elusive Factor in Organizational Effectiveness, San Francisco, CA: Jossey-Bass, pp. 122-60.

Shah, S.J.A. (2006), 'Educational leadership: an Islamic perspective', British Educational Research Journal, 32 (3), 363-85.

Sharabi, H. (ed) (1990), 'Introduction', in Theory, Politics, and the Arab World: Critical Responses, New York: Routledge.

Sharp, J.M. (2005), The Broader Middle East and North Africa Initiative: An Overview, Washington, DC: Congressional Research Service, The Library of Congress, accessed 9 December 2010 at www.fas.org/sgp/crs/mideast/RS22053. pdf.

Sinclair, A. (2005), Doing Leadership Differently: Gender, Power and Sexuality in a Changing Business Culture, revised edn, Carlton, VIC.: Melbourne University Press.

Sinclair, A. (2007), Leadership for the Disillusioned: Moving Beyond Myths and Heroes to Leading that Liberates, Sydney, NSW: Allen and Unwin.

Stogdill, R.M. (1950), 'Leadership membership organization', Psychological Bulletin, 47, 1-14.

Storey, J. (2004), 'Changing theories of leadership and leadership development', in J. Storey (ed.), Leadership in Organisations: Current Issues and Key Trends, London: Routledge.

Sudan Commerce News (2010), UAE, Saudi to lease more farmlands, 25 November, accessed 15 December 2010 at http://sdeconews.com/story-z3426498.

Swan S.E., V. Stead and C.J. Elliott (2009), 'Research futures: women, diversity and management learning', Management Learning, 40 (4), 431-7.

Syed, J. and F. Ali (2011), 'The white woman's burden: from colonial civilisation to third world development', Third World Quarterly, 32 (2), 349-68.

Syed, J. (2010), 'Reconstructing gender empowerment', Women's Studies International Forum, 33, 283-94. 
Tolba, M.K. and N.W. Saab (eds) (2009), Arab Environment: Climate Change, Beirut: Arab Forum for Environment and Development.

Umar-ud-al-Muhammad (1991), The Ethical Philosophy of al Ghazzali, Lahore, Pakistan: Sh. Muhammad Ashraf.

United Nations (n.d.), 'Millennium goals: background', accessed 18 December 2010 at www.un.org/millenniumgoals/bkgd.shtml.

United Nations Development Programme (UNDP) 2003, Arab Knowledge Report.

UNDP (2009a), Human Development Report 2009: Overcoming Barriers: Human Mobility and Development, New York: UNDP.

UNDP (2009b), Arab Human Development Report: Challenges to Human Security in the Arab States, New York: UNDP.

UNDP (2010), Human Development Report 2010: The Real Wealth of Nations, New York: UNDP.

Utting, P. (ed.) (2006), Reclaiming Development Agendas: Knowledge, Power and International Policy Making, Basingstoke: Palgrave Macmillan.

De Vries, K. (1994), 'The leadership mystique', in K. Grint (ed.) (1997), Leadership: Classical, Contemporary and Critical Approaches, Oxford: Oxford University Press.

Western, S. (2008), Leadership: A Critical Text, Thousand Oaks, CA: Sage Publications.

Wiefen, B. (2008), 'Liberalising autocracies in the Gulf region: reform strategies in the face of a cultural-economic syndrome', World Development, 36, (12), 2586-604.

Wilson, R. (1985), 'Islamic business: theory and practice', Economist Intelligence Unit Special Report, no. 221, London.

Wilson, R. (1995), Economic Development in the Middle East, London: Routledge.

Woodward, J. (1970), Industrial Organization: Behaviour and Control, New York: Oxford University Press.

Woolcock, M. (1998), 'Social capital and economic development: toward a theoretical synthesis and policy framework', Theory Culture and Society, 27 (2), 151-208.

Woolgar, S. (1978), Knowledge and Reflexivity: New Frontiers in the Sociology of Knowledge, London: Sage Publishers.

World Bank (2008), 'Education and migration', in The Road not Travelled. Education and Reform in the Middle East and Africa, MENA Development Report, The World Bank, Washington DC, pp. 245-77.

Yukl, G. (2008), 'How leaders influence organizational effectiveness', The Leadership Quarterly, 19, 708-22.

Yukleyen, A. (2009), 'Redefining "Islam" and "Europe" in Turkey's European Union membership process', paper presented at the annual meeting of the ISA's 50th annual convention, 'Exploring the Past, Anticipating the Future', New York Marriott Marquis, 15 February, New York.

Zaleznik, A. (1992), 'Managers and leaders: are they different?', Harvard Business Review, March - April.

Zaman, N. and M. Asutay (2009), 'Divergence between aspirations and realities of Islamic economics: a political economy approach to bridging the divide', IIUM Journal of Economics and Management, 17 (1), 73-96. 